\title{
Hydrologic Changes in Indian Subcontinental River Basins (1901-2012)
}

\author{
HARSH L. SHAH AND VIMAL MiSHRA \\ Civil Engineering, Indian Institute of Technology Gandhinagar, Gujarat, India
}

(Manuscript received 22 November 2015, in final form 7 July 2016)

\begin{abstract}
Long-term (1901-2012) changes in hydroclimatic variables in the 18 Indian subcontinental basins were examined with hydrology simulated using the Variable Infiltration Capacity model (VIC). Changepoint analysis using the sequential Mann-Kendall test showed two distinct periods (1901-47 and 1948-2012) for the domain-averaged monsoon season (June-September) precipitation. Hydrologic changes for the entire water budget were estimated for both periods. In the pre-1948 period, a majority of the river basins experienced increased monsoon season precipitation, evapotranspiration (ET), and surface water availability (as defined by total runoff). Alternatively, in the post-1948 period, monsoon season precipitation declined in 11 of the 18 basins, with statistically significant trends in one (the Ganges basin), and most (15) basins experienced significant warming trends. Additionally, in the post-1948 period, the mean monsoon season ET and surface water availability declined in eight (with significant declines in four) basins. The results indicate that changes in ET and surface water availability in the pre- and post-1948 periods were largely driven by the changes in the monsoon season precipitation rather than air temperature, despite prominent warming after 1975. Coupled modes of variability of sea surface temperature (SST) and surface water availability indicated El NiñoSouthern Oscillation (ENSO) as the leading mode. The second mode was identified as the trend mode for surface water availability in the subcontinental river basins, which was largely driven by SST anomalies in the Indian and Atlantic Ocean regions. This indicates that surface water availability in India's subcontinental basins may be affected in the future in response to changes in large-scale climate variability.
\end{abstract}

\section{Introduction}

Climate change and weak summer monsoons put tremendous pressure on water resources in the Indian subcontinental region (Mishra et al. 2012). A decline in the monsoon rainfall has been observed during the last few decades (Mishra et al. 2012; Koll et al. 2015), which can be attributed to large-scale climate variability (Kumar et al. 1999) and the influence of atmospheric aerosols (Bollasina et al. 2011). Air temperature over India and in other regions of the subcontinent has been rising substantially in recent decades (Kumar et al. 2011), which is consistent with the trends in global mean temperatures (Hansen et al. 2006). Food and freshwater security

Supplemental information related to this paper is available at the Journals Online website: http://dx.doi.org/10.1175/ JHM-D-15-0231.s1.

Corresponding author address: Vimal Mishra, Civil Engineering, IIT Gandhinagar, Shed-3, Room 216, VGEC Campus, Chandkheda, Ahmedabad, Gujarat 382424, India.

E-mail: vmishra@iitgn.ac.in remains one of the greatest challenges that the subcontinent may face in the future. Increasing population along with climate change is projected to affect water availability and storage, which may be crucial for freshwater security (Vörösmarty et al. 2000).

Climate change can substantially affect water availability in Indian subcontinental basins (Immerzeel et al. 2010; Mishra and Lilhare 2016). For instance, Immerzeel et al. (2010) reported that climate change will reduce the meltwater availability from glaciers, thus affecting the Asian water towers. They found that the Brahmaputra and Indus basins are the most susceptible to reduction of flow under the projected climate change, which in turn will threaten food security in these basins. Mishra and Lilhare (2016) evaluated hydrologic sensitivity of the Indian subcontinental basins and reported that surface water availability in the majority of the basins is more sensitive to the monsoon season precipitation than air temperature. However, climate change projections of the monsoon season precipitation are largely uncertain (Turner and Annamalai 2012; Asharaf and Ahrens 2015; Mishra 2015), indicating both projected increase (Menon et al. 2013) and decline (Ashfaq et al. 2009), which may 
cause frequent extreme wet and dry events. For instance, severity of droughts is projected to increase in many parts of the Indian subcontinental basins under climate change (Mishra et al. 2014).

Despite several implications of climate change on water resources in the Indian subcontinent, efforts, so far, have been limited to study changes in surface water availability at regional or river basin scales. Moreover, our understanding on water budget in the subcontinental river basins, which is important for the ambitious projects such as interlinking of rivers, is limited. We provide a long-term (1901-2012) assessment of changes in surface water availability in the Indian subcontinental river basins. We estimate water budget in the Indian subcontinental river basins for the pre- and post-1948 periods. Moreover, we highlight the influence of large-scale climate variability on surface water availability in the subcontinental river basins. We address the following questions:

1) How has surface water availability, as measured by total runoff (TR), changed across India's subcontinental river basins?

2) What are the key drivers of those changes [e.g., precipitation $P$, evapotranspiration (ET), and air temperature $T_{a}$ ] during the monsoon season?

3) How are these trends related to large-scale climate patterns, as measured by sea surface temperatures, and what does this mean for future surface water availability?

\section{Data and methods}

\section{a. Datasets}

We analyzed long-term changes in precipitation, air temperature, ET, and surface water availability [defined by total runoff (runoff plus base flow)] in the monsoon season [June-September (JJAS)] during the period of 1901-2012. We obtained $0.25^{\circ}$ daily observed precipitation data for the period of 1901-2012 from the India Meteorological Department (IMD; Pai et al. 2014a) for the Indian region. As parts of the Indus, Ganges, and Brahmaputra basins fall outside India, we used daily precipitation data for the same period from Sheffield et al. (2006). We obtained observed daily maximum and minimum temperatures and wind speed at $0.25^{\circ}$ spatial resolution from Sheffield et al. (2006) for the period of 1901-2012, as long-term data are not available from IMD. We compared the monsoon season precipitation from IMD and Sheffield et al. (2006) and found that both datasets are consistent for year-to-year variability and bias (Fig. S2 in the supplemental material). Temperature data from IMD and Sheffield et al. (2006) for a common period (1951-2012) agree reasonably well (Fig. S3 in the supplemental material), as reported in Mishra et al. (2014). Air temperature from Sheffield et al. (2006) showed a negative bias in Jammu and Kashmir region, which may be due to inconsistencies in IMD data because of sparse gauge stations in hilly regions (Shah and Mishra 2015). Correlation analysis between precipitation and air temperature from IMD and Sheffield et al. (2006) for the monsoon season showed that both the datasets are consistent (Fig. S4 in the supplemental material).

We selected 18 Indian subcontinental basins to evaluate long-term changes in the hydrologic variables (Fig. 1). The observed streamflow data for most of the basins located in India are available through the Water Resources Information System of India (IWRIS; www. india-wris.nrsc.gov.in), which is a joint venture of the Central Water Commission (CWC), Ministry of Water Resources, Government of India, and the Indian Space Research Organisation (ISRO). As observed streamflow data for transboundary river basins are classified, data for the Ganges, Brahmaputra, and Indus basins were obtained from the global river discharge database from the Center for Sustainability and the Global Environment (SAGE; https://nelson.wisc.edu/sage/data-andmodels/riverdata/), which provides monthly mean river discharge data at 3500 gauge stations across the globe. We selected streamflow stations that were mostly located upstream of major reservoir and water storage structures. However, as the observed data may be partially affected by human interventions, we used satellite-driven ET and soil moisture to evaluate model performance spatially. We obtained monthly evapotranspiration from Mu et al. (2011), which is based on the Moderate Resolution Imaging Spectroradiometer (MODIS) satellite and available at $0.5^{\circ}$ resolution for the time period $2000-07$. Mu et al. (2011) reported that the MOD 16 ET product can be used to estimate actual ET with satisfactory accuracy in Asia. Satellite-driven soil moisture was obtained from the European Space Agency Climate Change Initiative (ESA-CCI), which is available from 1979 onward at $0.25^{\circ}$ spatial and daily temporal resolution. The satellite soil moisture is a merged product from the various sensors (Hollmann et al. 2013) and has been used to evaluate hydrologic simulations in India (Mishra et al. 2014).

\section{b. The VIC}

The Variable Infiltration Capacity model (VIC; Liang et al. 1996) that simulates water and energy fluxes in each grid cell was used to obtain simulated ET and surface water availability in the Indian subcontinental basins for the period of 1901-2012. VIC represents subgrid variability of elevation, soil, and vegetation 


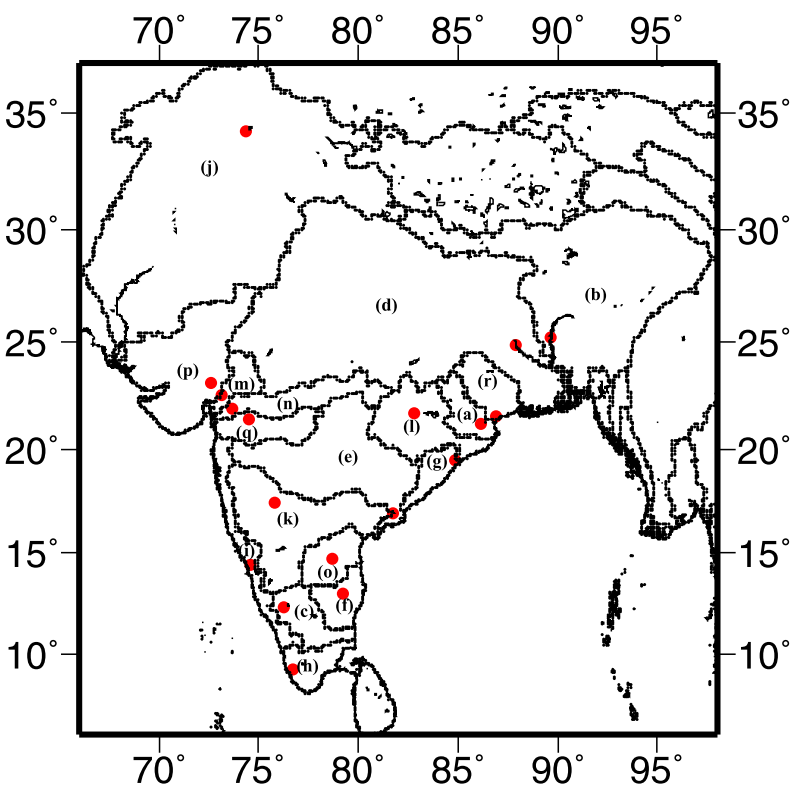

FIG. 1. Indian subcontinental river basins and the selected gauge stations (red circles) that were used for VIC calibration and evaluation. Letters follow the same order of basins presented in Figs. 2 and 3.

(Gao et al. 2010). We used vegetation parameters that were extracted from the Advanced Very High Resolution Radiometer (AVHRR) global land-cover information that is available at $1-\mathrm{km}$ spatial resolution (Sheffield and Wood 2007; Hansen et al. 2000). We obtained Harmonized World Soil Database (HWSD), version 1.2 , soil data to develop soil parameters to run VIC in the subcontinental river basins. VIC was calibrated and evaluated using the observed streamflow data at the gauge stations that were not (or least) affected by the human interventions (e.g., dams and reservoirs). We calculated Nash-Sutcliffe efficiency (NSE; Nash and Sutcliffe 1970) and correlation coefficient $r$ between observed and simulated monthly streamflow to evaluate the VIC performance (Table S1 in the supplemental material). Additionally, satellite soil moisture and evapotranspiration were used to evaluate the performance of VIC.

\section{c. The VIC calibration and evaluation}

VIC was successfully calibrated (Fig. 2, Table S1 in the supplemental material) and evaluated against observed streamflow for the subcontinental river basins using the six soil parameters as described in Mishra et al. (2010). Out of 18 basins, 13 showed NSE greater than 0.6 during calibration, while 15 basins showed NSE higher than 0.6 during evaluation (Table S1 in the supplemental material). We noticed a poor performance at a few gauge stations (Cauvery, Sabarmati, and coastal basins), which can be attributed to quality of streamflow data or other input parameters related to soil and vegetation. Additionally, VIC reproduced remotely sensed monthly ET and soil moisture well (Figs. 3, 4), which highlights that the model can be used for an assessment of the role of climate variability on surface water availability in the region. VIC-simulated ET showed good correlation (higher than 0.9) for most of the selected river basins. Monthly ET from VIC was underestimated for the Brahmaputra and Western Ghats basins (Fig. 3), which can be attributed to high water availability in these basins that was not successfully reproduced by VIC. Other than satellite ET, VIC performed reasonably to reproduce satellite soil moisture in the subcontinental river basins during the period of 1979-2012 (Fig. 4). Spatial patterns of correlation coefficient between the VIC-simulated soil moisture and satellite-based soil moisture showed a good agreement except for the Indus, Brahmaputra, and east coast basins (Fig. 4). While the model performance was satisfactory for the majority of the basins, hydrologic changes and water budget estimates for the basins with poor performance may be less reliable and will need improvements in the future.

\section{d. Analysis approach}

We selected two periods (1901-47 and 1948-2012) using the analysis based on a 10-yr moving average of domain-averaged monsoon season precipitation as well as changepoint detection based on the sequential MannKendall test (Sneyers 1990). The sequential MannKendall test has been widely used for changepoint estimation (Olmo and Alados-Arboledas 1995), and further details can be obtained from Mishra et al. (2011). Domain-averaged precipitation time series for the monsoon season showed a changepoint in 1947 (Fig. 5). The monsoon season showed an increasing trend before 1947 and declining trends after 1947. Similar to the monsoon season precipitation, the other water budget variables (i.e., ET and surface water availability) also showed the changepoint in 1947, indicating that these are largely driven by the summer monsoon season rainfall (Figs. $5 \mathrm{c}, \mathrm{d}$ ). However, the domain-averaged air temperature for the monsoon season showed a changepoint in 1975, which could be attributed to climate warming (Fig. 5b). The analysis was performed based on the changepoint in 1947 as all the water budget variables (e.g., precipitation, ET, and surface water availability) showed increasing trends for the period of 1901-47 and declining trends afterward. Therefore, the selected periods can be used to understand changes in surface water availability in the subcontinental river basins. Moreover, these periods can be used to diagnose the influence of large-scale climate variability on water resources in the subcontinent. Our 


\section{Streamflow Calibration \& Evaluation}
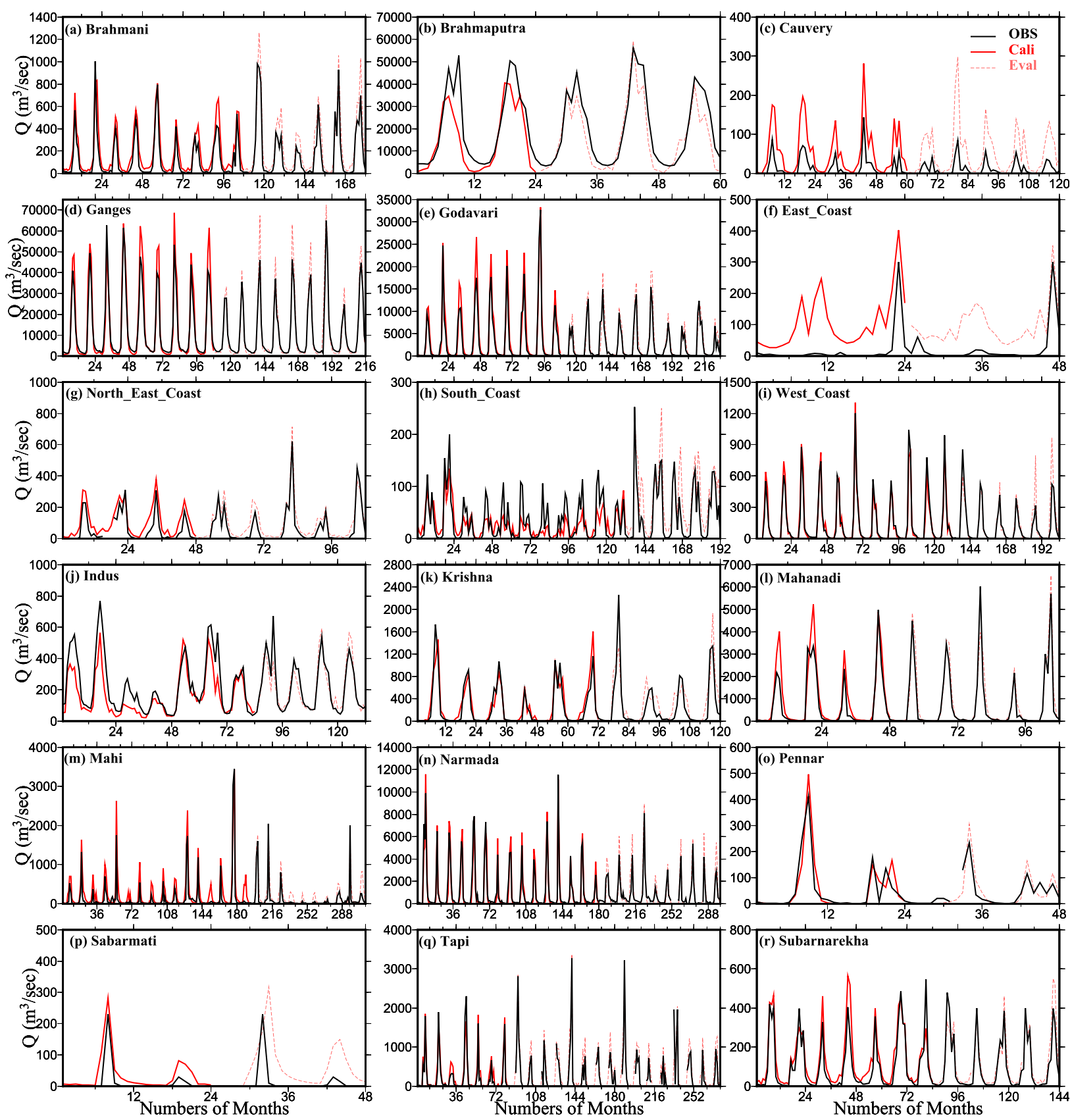

FIG. 2. Comparison of monthly observed (black) and VIC-simulated (red) streamflow $\left(\mathrm{m}^{3} \mathrm{~s}^{-1}\right)$ at the selected gauge stations for a combined [calibration (solid red) and evaluation (dotted red)] period (Table S1 in the supplemental material).

analysis is based on the changepoint in domainaveraged time series of hydroclimatic variables and individual basins may have different changepoints (Table S7 in the supplemental material). Differences in changepoint for basins and the entire domain can be attributed to the influence of large-scale climate variability and occurrence of extreme hydroclimatic events.
We also notice a disparity in the changepoint of monsoon season precipitation and surface water availability in the west coast and Mahi basins (Table S7 in the supplemental material). The west coast is one of the wettest regions in India while the Mahi basin is located in the semiarid western India. Therefore, extreme dry or wet years in these basins may affect the changepoint; 


\section{Evapotranspiration}
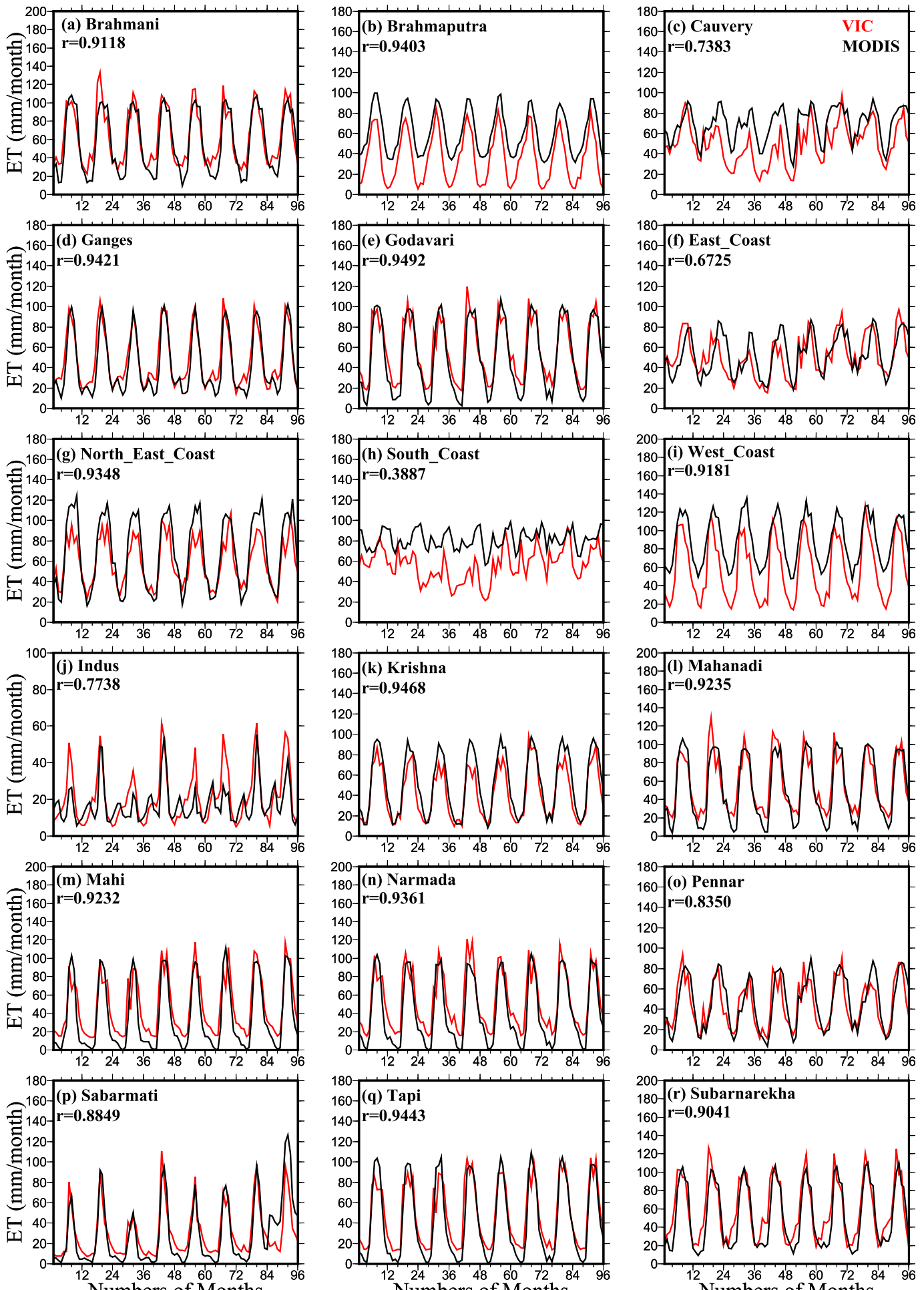

Numbers of Months

Numbers of Months

FIG. 3. Comparison of basin-averaged monthly ET ( $\mathrm{mm}$ ) from MODIS (black) and VIC (red) for the period of $2000-08$. 

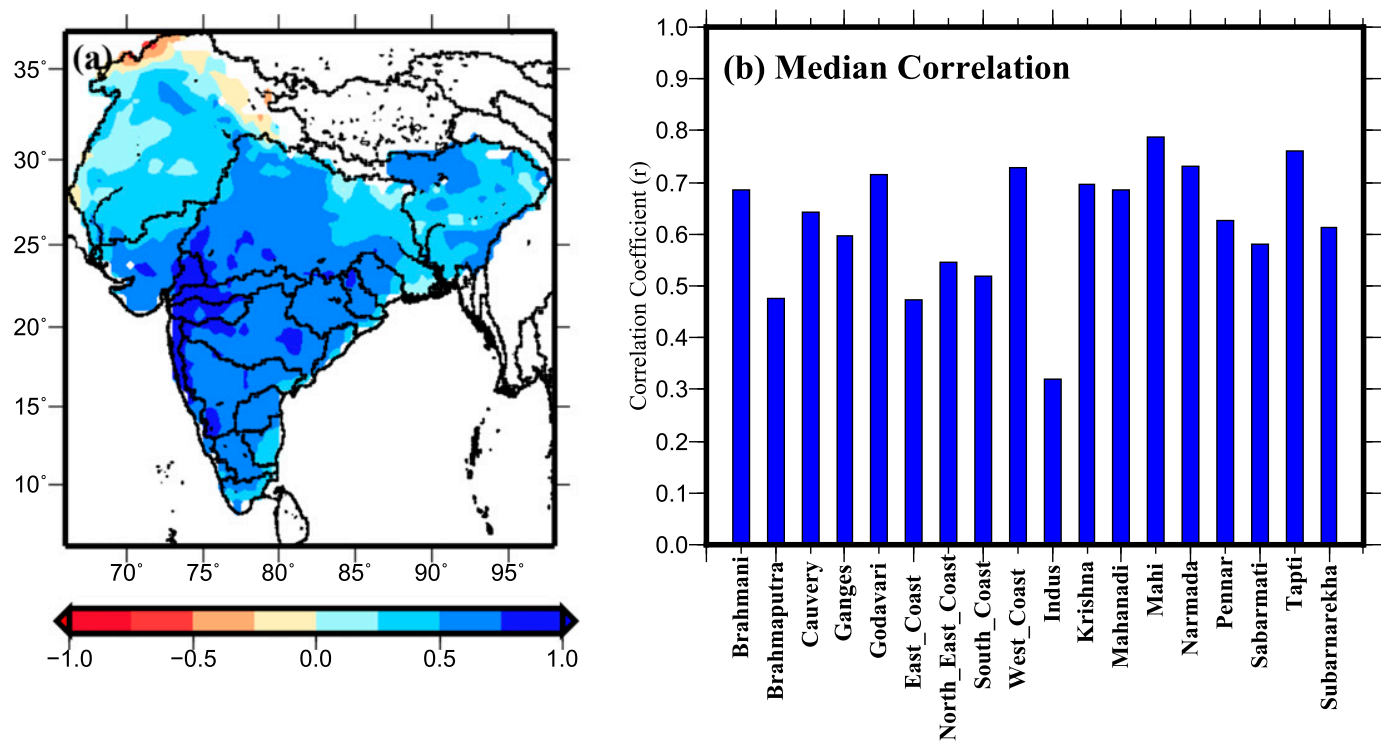

FIG. 4. (a) Correlation between surface soil moisture from ESA-CCI and VIC for the period of 1979-2007 and (b) median correlation for the selected river basins in the Indian subcontinent.

however, in-depth basin-specific studies are required to better understand the causes of such disparity in these basins.

We carefully evaluated the role of changes in the number of observation stations and precision of instrument on trends and variability of the monsoon season precipitation (Fig. S1 in the supplemental material). Comparison between all-India precipitation from fixed stations (Rajeevan et al. 2008) and variable stations (Pai et al. 2014a) showed that interannual variability and trends in both the datasets are consistent, indicating that trends and variability are not influenced by the number of stations and precision of measurement. For detailed information, please refer to Pai et al. (2014b).

Changes in the selected hydroclimatic variables were estimated using a nonparametric Mann-Kendall trend test (Mann 1945) and Sen's slope (Sen 1968). Statistical significance in trend analysis was estimated at the $5 \%$ significance level. Since hydroclimatic variables often show autocorrelation, the effect of serial and spatial autocorrelations was removed using the method described in Yue and Wang (2002). The Mann-Kendall method has been widely used for trend detection in hydroclimatic variables at regional and global scales (Mishra and Lettenmaier 2011; Mishra et al. 2015). We estimated changes in the mean of the hydroclimatic variables for the pre- and post-1948 periods. For air temperature we also estimated trends in the post-1975 period, during which a significant warming was observed in most of the subcontinental river basins. Statistical significance in change in mean was estimated using the two-sided rank-sum test at 5\% significance level.

\section{e. SVD analysis}

To understand the role of large-scale climate variability on surface water availability in the subcontinental region, the singular value decomposition (SVD) analysis was performed on sea surface temperature (SST) and surface water availability for the monsoon season. We obtained long-term (1901-2012) monthly sea surface temperature data from the National Centers for Environmental Information's Extended Reconstructed SST, version 3b (ERSST.v3b) at $2^{\circ}$ spatial resolution (Smith et al. 2008). The monthly SST departure field was estimated by subtracting global mean monthly SST from mean monthly SST for the monsoon season from each grid cell as described in Mishra et al. (2012). Using the SST departure field and surface water availability for the monsoon season, we performed the SVD analysis to obtain the coupled modes of variability. Strength of the relationship between surface water availability in the Indian subcontinental basins and global SST is expressed using heterogeneous correlation. Detailed information on the SVD analysis can be obtained from Bretherton et al. (1992). We performed the SVD analysis for the two periods (e.g., 1901-47 and 1948-2012) that were obtained using the changepoint analysis. For each period, SST departure field and surface water availability for the monsoon season were used for the analysis and the leading two modes of coupled variability were selected. Temporal dimensions for both (SST departure field and 

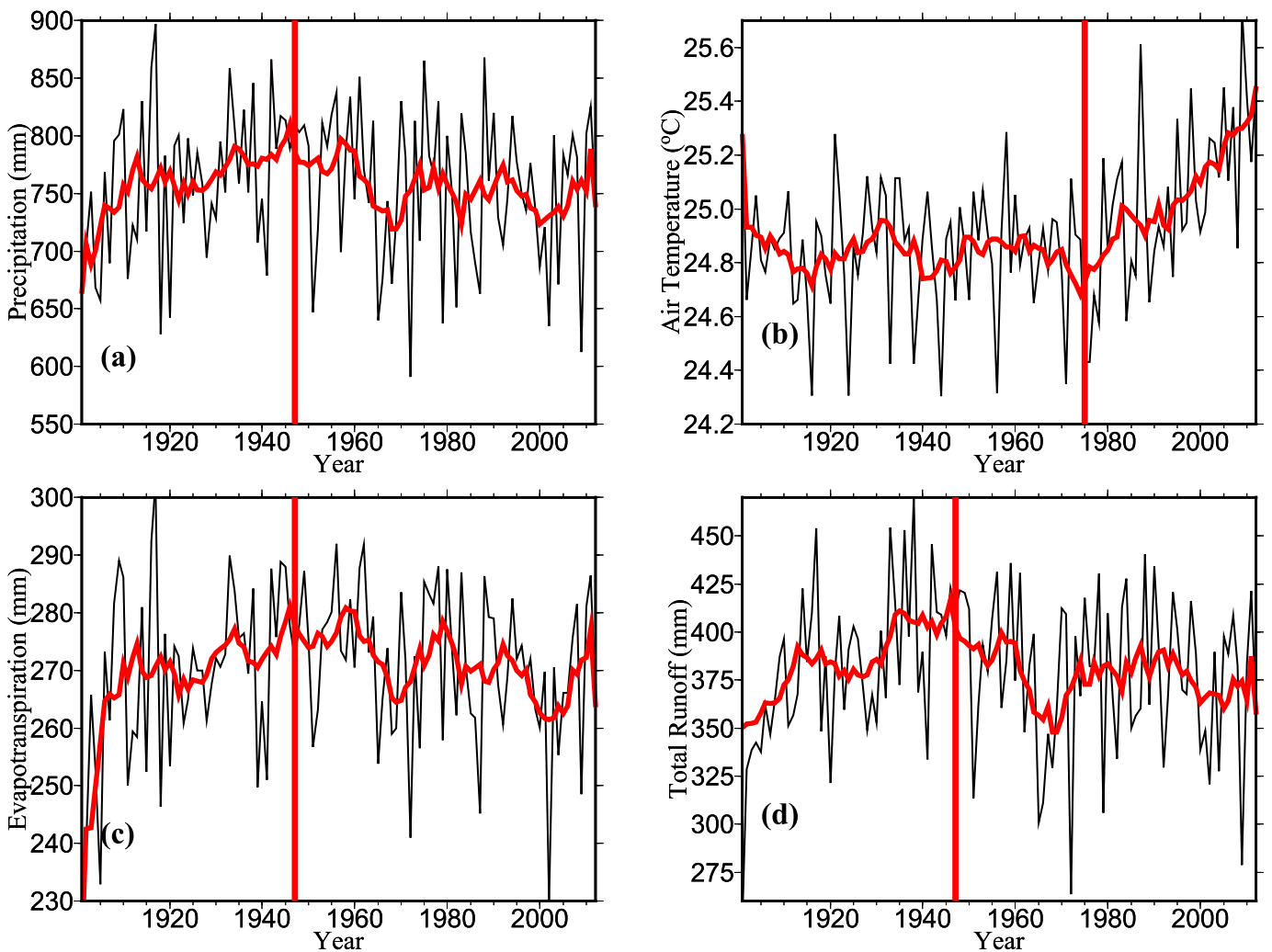

FIG. 5. (a) Domain (i.e., Indian subcontinent)-averaged monsoon season $P$ (black) and 10 -yr moving average (red) for the period of 1901-2012. (b) As in (a), but for $T_{a}$. (c) As in (a), but for ET. (d) As in (a), but for TR. The vertical line in each panel shows the changepoint estimated using the sequential Mann-Kendall test.

surface water availability) were 47 (1901-47) and 65 (1948-2012) years for the two selected periods. A crosscovariance matrix was estimated using spatial and temporal fields and the SVD analysis was applied. The SVD of a cross-covariance matrix provided two spatially orthogonal sets of singular vectors and a related set of singular values. Each pair describes squared covariance fraction (SCF) of the two variables (i.e., SST departure field and surface water availability). The Spearman rank correlation was used to describe the strength of relationship between SST departure field and surface water availability during the monsoon season in the subcontinental river basins.

\section{Results and discussion}

\section{a. Changes in the monsoon season precipitation}

Figure 6 shows mean monsoon season precipitation in the Indian subcontinental basins and trends during the periods of 1901-47 and 1948-2012. Mean monsoon season precipitation is higher (more than $1800 \mathrm{~mm}$ ) in the Western Ghats and northeastern regions (Fig. 6a). Between 1901 and 1947, statistically significant trends in the monsoon season precipitation were found in the subcontinental river basins (Fig. 6b). For instance, parts of the Ganges, Brahmaputra, Godavari, Narmada, and Mahanadi experienced significant increases (more than $5 \mathrm{~mm} \mathrm{yr}^{-1}$ ) in the monsoon season precipitation (Fig. 6b). Reduction in the monsoon season precipitation was observed in many basins during the period of 1948-2012 (Fig. 6c). Changes in the monsoon season precipitation during the pre- and post-1948 periods were prominent in the central part of the study domain, which affected surface water availability in many basins (Figs. 6b,c). We find that out of the 18 subcontinental river basins, seven experienced significant increases $(p$ value $<0.05)$ in the monsoon season precipitation during the period of 1901-47 (Fig. 6d, Table S2 in the supplemental material). Between 1901 and 1947, a prominent increase in the monsoon season precipitation was noticed in the Brahmaputra, Brahmani, Godavari, west coast, Mahanadi, Mahi, and Tapi basins (Table S2 in the supplemental material). While 11 out of 18 basins showed declining trends, only one (the Ganges basin) showed a significant reduction in the monsoon season precipitation during the period of 1948-2012 (Table S2 in the supplemental 

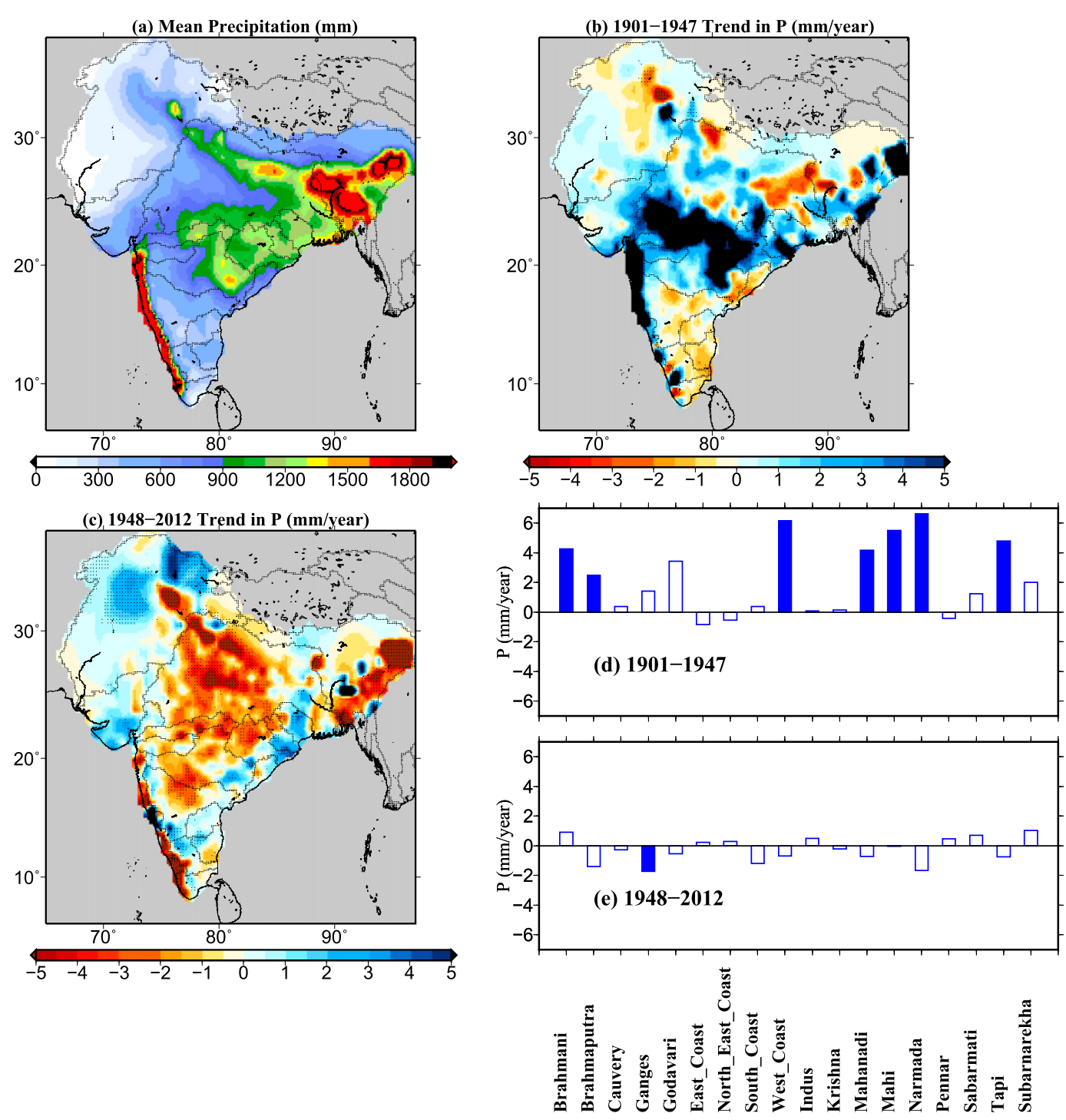

FIG. 6. (a) Mean $P$ for the monsoon season during the period of 1971-2000; (b) trend in $P\left(\mathrm{~mm} \mathrm{yr}^{-1}\right)$ during the period of 1901-47 estimated using the Mann-Kendall test; and (c) as in (b), but for the period of 1948-2012. (d) Trend in the monsoon season $P$ for the selected river basins for the period of 1901-47; and (e) as in (d), but for 1948-2012. Hollow bars in (d) and (e) show nonsignificant trends while solid bars represent significant trends for the selected periods of 1901-47 and 1948-2012. Long-term mean values for $P$ are presented in Table 2.

material, Fig. 6e). Our results highlight that changes in the monsoon season precipitation can influence surface water availability in the region.

Between 1948 and 2012, an increasing trend in the monsoon season precipitation was observed in the Indus basin, but the Ganges and Brahmaputra basins experienced a decline in the same period. However, an increase in the monsoon season precipitation in the upper Indus basin was substantially lesser in magnitude than that of decline in the Ganges and Brahmaputra basins. Declining trend in the monsoon season precipitation has been reported in several studies (Mishra et al. 2012; Bollasina et al. 2011), which may be attributed to warming in the Indian Ocean (Mishra et al. 2012; Koll et al. 2015) and to the atmospheric aerosols (Bollasina et al. 2011). Mishra et al. (2012) reported a prominent pattern of year-toyear variability in the Indian summer monsoon rainfall in which the declining trend in the Ganges basin is linked with positive SST anomalies in the Indian Ocean. The increasing trend in the monsoon season precipitation during the period of 1901-47 and decline afterward might be also linked with the multidecadal variability (Krishnan and Sugi 2003). For instance, the summer monsoon season precipitation in the region is linked 
with the interdecadal variability of SST in the Pacific Ocean (Goswami et al. 2006) and Atlantic multidecadal oscillation (AMO). During the warm phase of AMO, the region receives positive anomalies in the summer monsoon precipitation (Goswami et al. 2006).

\section{b. Changes in the monsoon season air temperature}

To understand a linkage between surface water availability and climate warming, we estimated the trend $\left[\left({ }^{\circ} \mathrm{C}\right) \mathrm{yr}^{-1}\right]$ in mean air temperature in the monsoon season using the nonparametric Mann-Kendall method for the periods of 1901-47 and 1948-2012 (Fig. 7, Table S3 in the supplemental material). As we find the changepoint for air temperature in 1975, the trend in the post-1975 period was also estimated. Mean monsoon season air temperature for the majority of the river basins is above $25^{\circ} \mathrm{C}$ while northern parts of the Indus, Ganges, and Brahmaputra basins remain at lower temperatures (Fig. 7a). The majority of the subcontinental basins witnessed stable monsoon season temperature with no significant change during the period of 1901-47 (Fig. 7b, Table S3 in the supplemental material). However, a significant warming was found in most of the subcontinental river basins during the period of 1948-2012 (Fig. 7c, Table S4 in the supplemental material). For instance, most of the selected basins experienced a significant warming $\left(\sim 0.01^{\circ}-0.02^{\circ} \mathrm{Cyr}^{-1}\right)$ during the period of 1948-2012 (Fig. 7c, Table S3 in the supplemental material). Furthermore, 15 out of 18 river basins showed significantly increasing trends in the monsoon season air temperature during the post-1948 period (Table S3 in the supplemental material). We find that trends in air temperature in the post-1948 period were largely contributed by warming in the period of 1975-2012 (Fig. 7d). Declining trends in air temperature during the monsoon season in the central Indus basin can be attributed to an increase in the monsoon season precipitation during the period of 1948-2012. For instance, Cook et al. (2003) attributed summer cooling in Nepal to increased rainfall in the region. Fowler and Archer (2006) also reported cooling during the summer in the upper Indus basin. Declining trends in air temperature during the monsoon season in the Indus basin can also be attributed to other factors related to aerosols (Ramanathan and Ramana 2005) and reduction in nighttime temperatures (Fowler and Archer 2006). An increase in air temperature during the monsoon season was more prominent in the peninsular basins than the basins located in the northern India, which can be associated with the effect of atmospheric aerosols in northern India.

\section{c. Changes in the monsoon season ET}

We estimated trends in VIC-simulated ET during the periods of 1901-47 and 1948-2012 (Fig. 8, Table S4 in the supplemental material). Influence of irrigation or other management practices on ET was not simulated, as we were interested in changes in water budget components due to large-scale climate variability. Higher monsoon season ET was exhibited in the regions that receive high precipitation (Fig. 8a). Mean monsoon season ET varied between 50 and $500 \mathrm{~mm}$ from the arid and semiarid west (lower Indus basin) to eastern region (e.g., Mahanadi River basin). Moreover, lower ET in the northern Himalayas and southern Indus basin can be attributed to low monsoon season precipitation in these regions (Fig. 8a). We find a significant increase in ET during the period of 1901-47 (Fig. 8b), which may be due to increased monsoon season precipitation. Increases in the monsoon season ET were more prominent in parts of the basins located in central India (Fig. 8b). Seven (Narmada, Tapi, Subarnarekha, Ganges, Godavari, south coast, and west coast) out of 18 basins experienced a significant ( $p$ value $<0.05$ ) increase in ET during the period of 1901-47 (Table S4 in the supplemental material, Fig. 8d). ET declined in 16 out of 18 basins during the period of 1948-2012, which can be attributed to a significant warming and a decline in the monsoon season precipitation (Fig. 8c, Table S4 in the supplemental material). Moreover, five (Tapi, Narmada, Mahi, Mahanadi, and Ganges) out of 18 basins showed a significant ( $p$ value $<0.05$ ) decline in the monsoon season ET during the period of 1948-2012 (Fig. 8e, Table S4 in the supplemental material). Changes in the modelsimulated ET may not be robust in the basins (e.g., Cauvery, Sabarmati, and coastal basins) that showed poor performance in the model calibration and evaluation. However, our results highlight implications of the declining monsoon season precipitation and increasing air temperature on surface water availability in the subcontinental river basins. Declines in the monsoon season ET during the observed record are due to depleted soil moisture conditions, which is consistent with the findings of Jung et al. (2010). McVicar et al. (2012) reported that observed rates of atmospheric demands have declined globally during the recent decades. Most of the river basins in the Indian subcontinent are not energy limited as they are in subtropical regions. Therefore, trends in ET in the preand post-1948 periods are directly related to the water availability, especially the monsoon season precipitation, in these basins, and declines (increases) in the monsoon season precipitation result in declines (increases) in the monsoon season evaporative demands. Despite an increase in air temperature during the period of 1948-2012 and more prominently after 1975, decreasing trends in ET in the subcontinental basins are largely controlled by the monsoon season precipitation, 


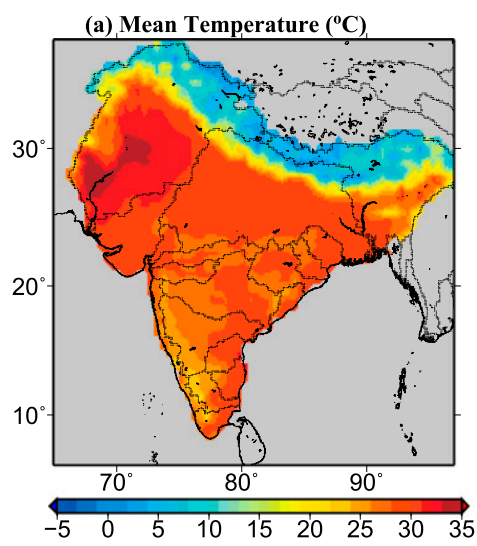

(c) 1948-2012 Change in $\mathrm{T}\left({ }^{\circ} \mathrm{C} /\right.$ year $)$
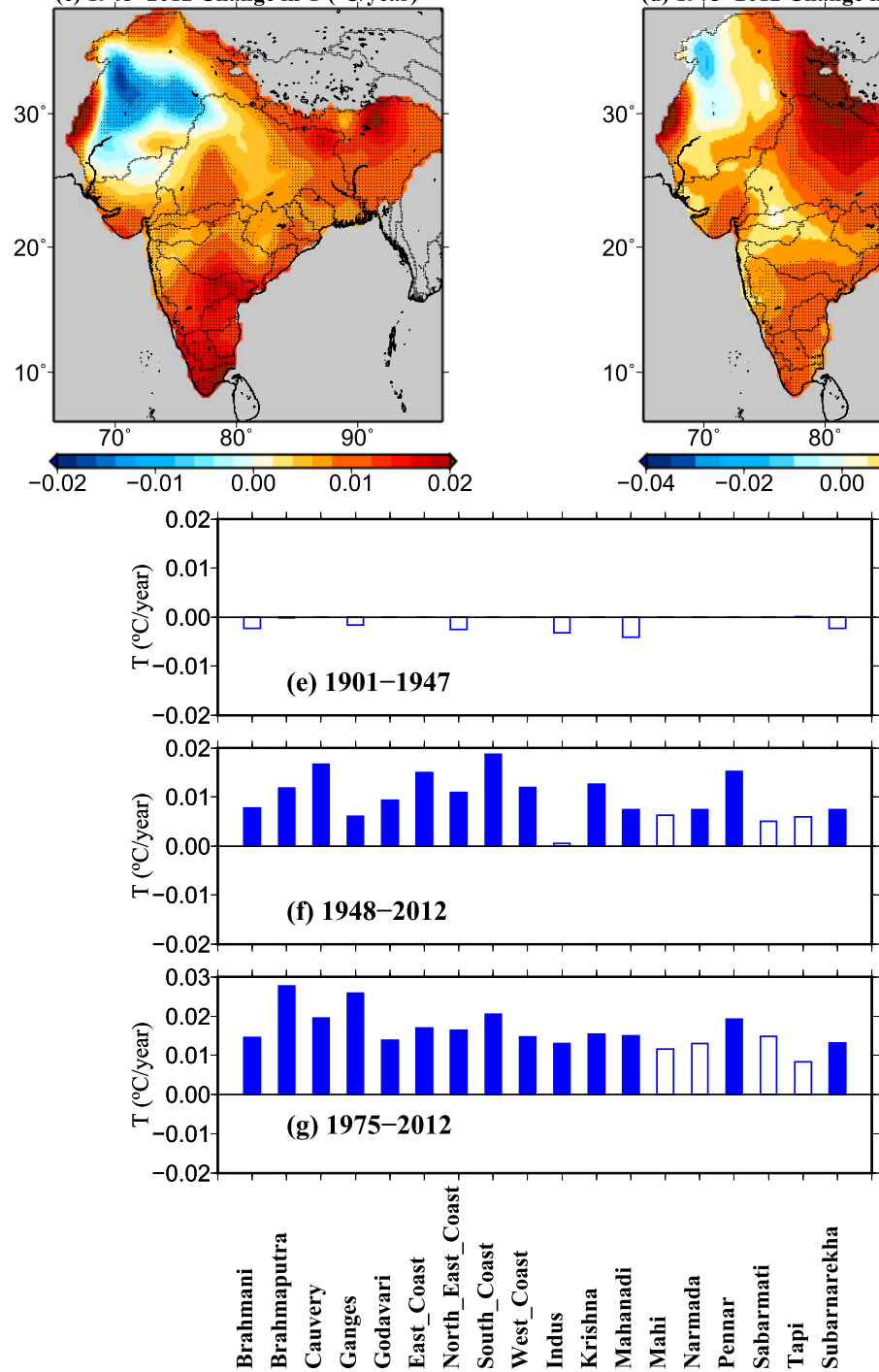

FIG. 7. (a) Mean $T_{a}$ for the monsoon season during the period of 1971-2000; (b) trend in $T_{a}\left[\left({ }^{\circ} \mathrm{C}\right) \mathrm{yr}^{-1}\right]$ during the period of 1901-47 estimated using the Mann-Kendall test; (c) as in (b), but for the period of 1948-2012; and (d) as in (b), but for the period of 1975-2012. (e) Trend in the monsoon season $T_{a}$ for the subcontinental river basins for the period of 1901-47; (f) as in (e), but for 1948-2012; and (g) as in (e), but for 1975-2012. Hollow bars in (e)-(g) show nonsignificant trends while solid bars represent significant trends for the selected periods of 1901-47, 1948-2012, and 1975-2012. Long-term mean values for $T_{a}$ are presented in Table 2. 
(a) Mean Evapotranspiration (mm)

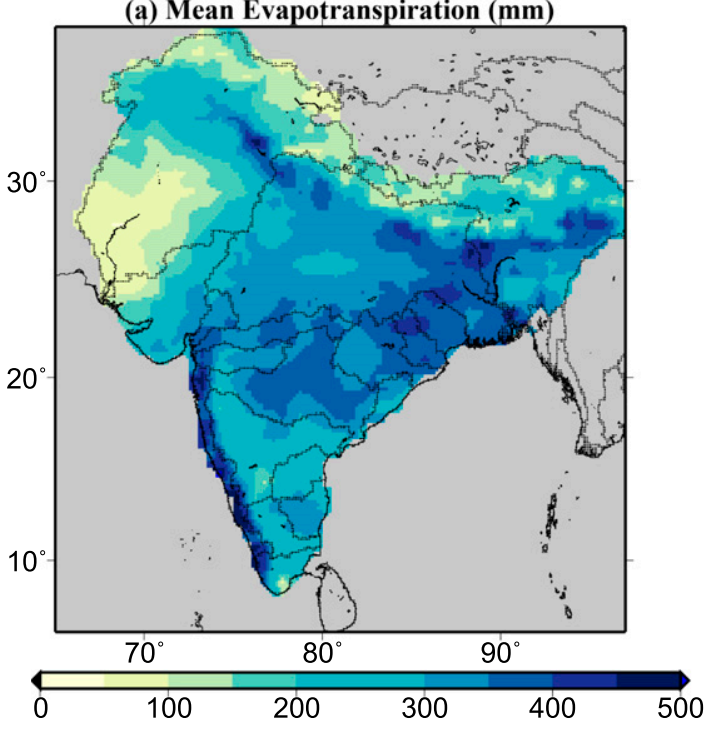

(c) 1948-2012 Trend in ET ( $\mathrm{mm} / \mathrm{year})$

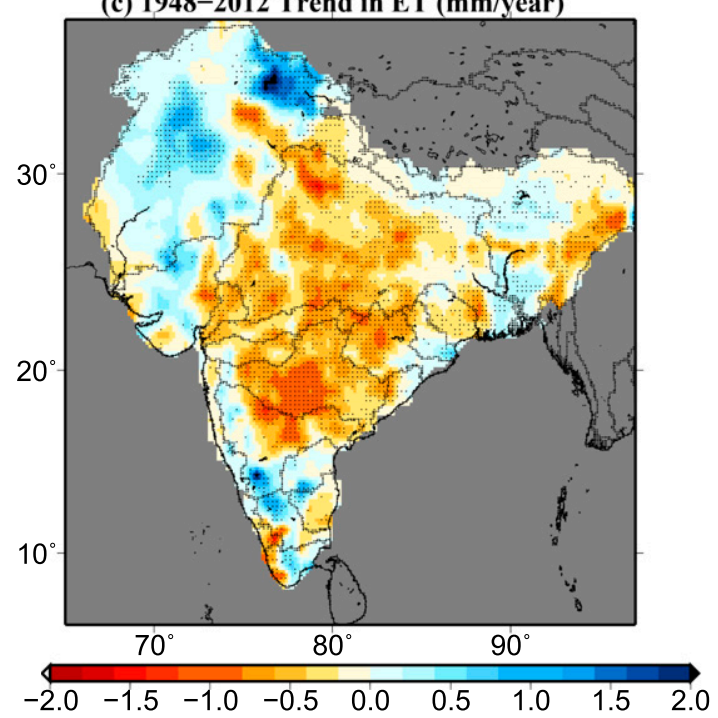

(b) 1901-1947 Trend in ET (mm/year)
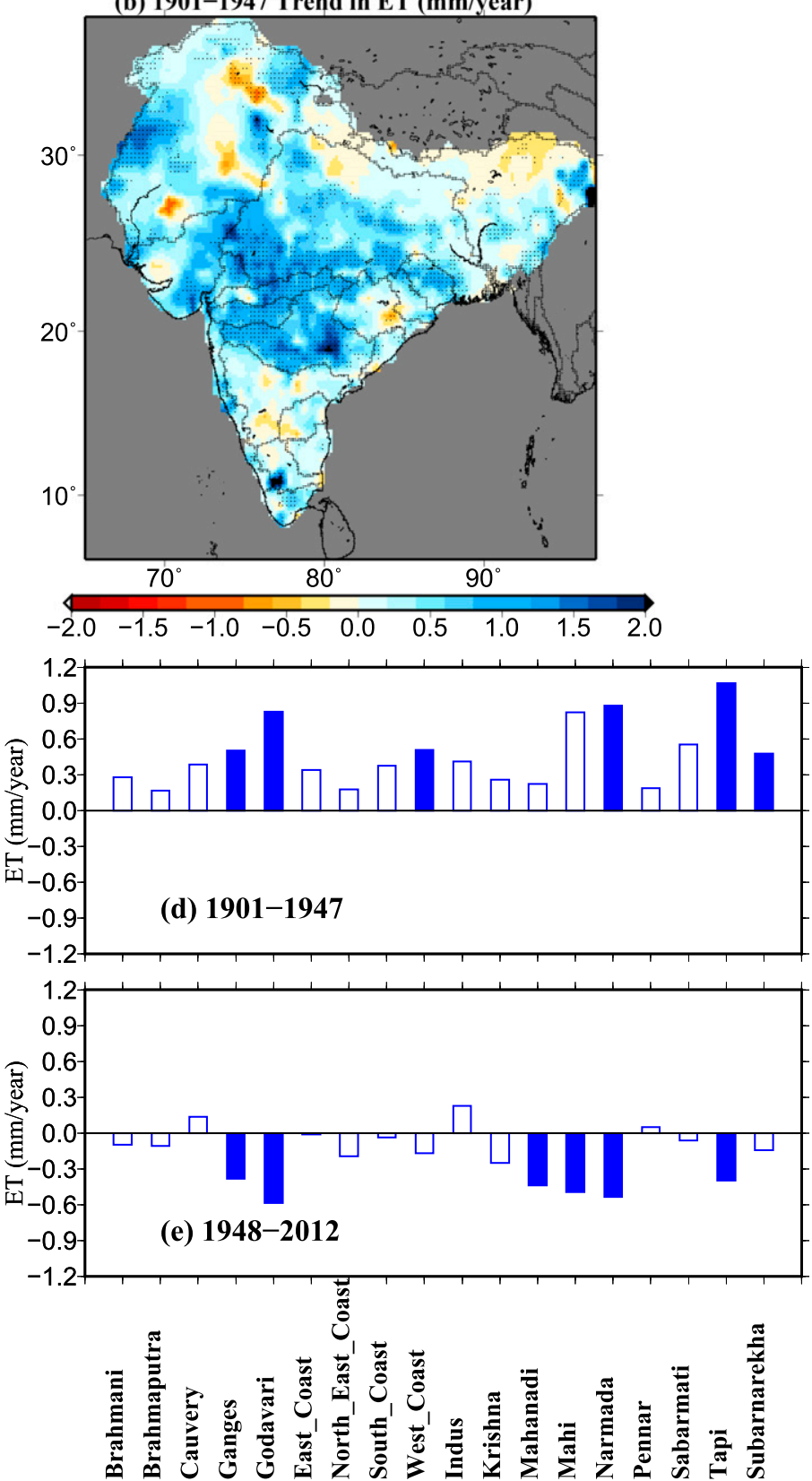

FIG. 8. (a) Mean ET for the monsoon season during the period of 1971-2000; (b) trend in ET ( $\mathrm{mm} \mathrm{yr}^{-1}$ ) during the period of 1901-47 estimated using the Mann-Kendall test; and (c) as in (b), but for the period of 1948-2012. (d) Trend in the monsoon season ET for the selected river basins for the period of 1901-47; and (e) as in (d), but for 1948-2012. Hollow bars in (d) and (e) show nonsignificant trends while solid bars represent significant trends for the selected periods of 1901-47 and 1948-2012. Long-term mean values for ET are presented in Table 2.

which is consistent with the findings of Mishra and Lilhare (2016).

\section{d. Changes in the monsoon season surface water availability}

Figure 9 shows the means and trends in the monsoon season surface water availability in the Indian subcontinental river basins. Mean monsoon season surface water availability varied between 50 and $1500 \mathrm{~mm}$ with higher values in the northeastern and Western Ghats regions and lower values in peninsular India and the western part of the Indian subcontinent (Fig. 9a). During the monsoon season, mean surface water availability was relatively less in the lower Indus, western 

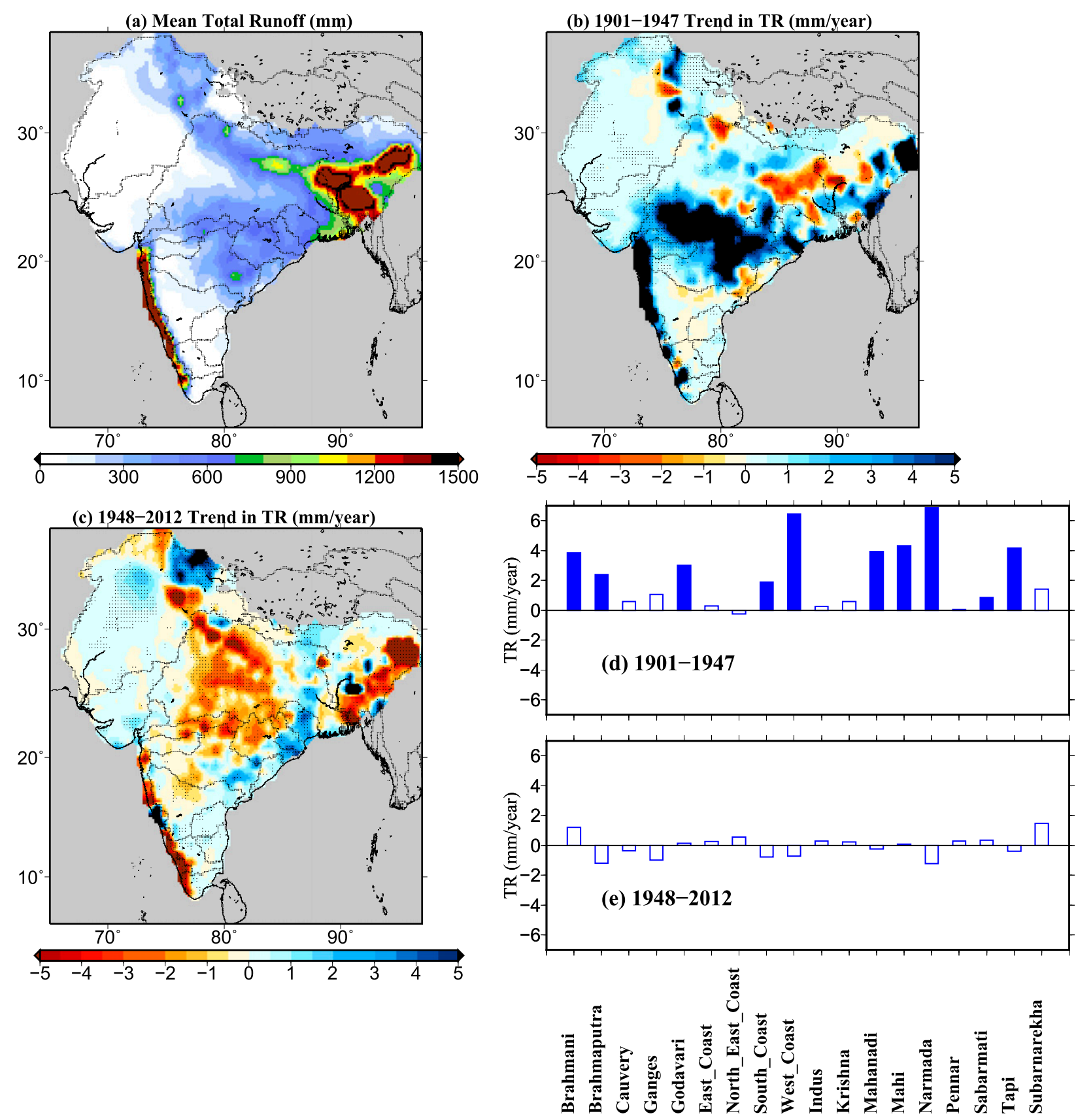

FIG. 9. (a) Mean TR for the monsoon season during the period of 1971-2000; (b) trend in TR ( $\mathrm{mm} \mathrm{yr}^{-1}$ ) during the period of $1901-47$ estimated using the Mann-Kendall test; and (c) as in (b), but for the period of 1948-2012. (d) Trend in the monsoon season TR for the selected river basins for the period of 1901-47; and (e) as in (d), but for 1948-2012. Hollow bars in (d) and (e) show nonsignificant trends while solid bars represent significant trends for the selected periods of 1901-47 and 1948-2012. Long-term mean values for TR are presented in Table 2.

Ganges, Sabarmati, and peninsular basins while higher in the Brahmaputra and river basins (e.g., Mahanadi, Brahmani, eastern Ganges, and Krishna) located in the core monsoon region (Fig. 9a). Significant increases in surface water availability were noticed during the period of 1901-47 (Fig. 9b, Table S5 in the supplemental material), which is consistent with the increase in the monsoon season precipitation during the same period. Between 1901 and 1947, an increase in surface water availability was more prominent in the basins located in central India and Western Ghats (Fig. 9b, Table S5 in the supplemental material). Out of 18 subcontinental basins, 
17 showed an increasing trend in surface water availability during the period of 1901-47 (Table S6 in the supplemental material, Fig. 9d). Significant increasing trends were observed in 10 out of 18 basins, suggesting that a majority of basins experienced elevated surface water availability during the pre-1948 period. A significant decline in surface water availability was noticed in parts of the Ganges, Brahmaputra, Narmada, and Mahanadi basins during the period of 1948-2012 (Figs. 9c,e, Table S5 in the supplemental material). However, significant trends in basin-averaged surface water availability were not found in any of the 18 subcontinental basins (Table S5 in the supplemental material, Fig. 9e). Similar to changes in the model-simulated ET, changes in the model-simulated surface water availability may be less reliable for the basins (Cauvery, Sabarmati, and coastal basins) where VIC did not perform well. It is noteworthy that despite increases in the monsoon season total runoff in the Indus and peninsular basins, surface water availability may not be compensated because of large differences in the magnitude in changes, which can cause serious implications on surface water availability and water demands.

\section{e. Changes in basin-averaged mean in the post-1948 period}

We estimated changes in basin-averaged mean monsoon season precipitation, ET, and surface water availability for the pre- and post-1948 periods (Fig. 10). Statistical significance in change in mean was estimated at the $5 \%$ significance level using the two-sided ranksum test. We find that all the subcontinental basins experienced warming in the monsoon season air temperature in the post-1948 period, which is predominantly caused during the last few decades (Fig. 10b). While many subcontinental basins showed a decline during the post-1948 period, only three basins (Brahmani, Brahmaputra, and Mahanadi) experienced significant declines in mean monsoon season precipitation (Fig. 10a). The Indus basin showed a significant increase $(\sim 14 \%)$ in mean monsoon season precipitation during the period of 1948-2012. We noticed that mean monsoon season precipitation declined by $5.0 \%, 4.0 \%$, and $7.0 \%$ in the Brahmani, Brahmaputra, and Mahanadi basins, respectively, in the post-1948 period in comparison to the pre-1948 period (Table 1). Mean monsoon season ET decreased significantly in the Brahmani, Brahmaputra, and Mahanadi basins while it increased significantly in the northeast coast and the Indus, Krishna, and Pennar basins during the period of 1948-2012 (Fig. 10c); however, results may not be robust for the coastal basins because of poor performance of VIC. A remarkable increase of $9 \%$ in mean monsoon season ET was found in the Indus basin, which can be attributed to the significant increase in precipitation (Fig. 10c, Table 1).

We find that changes in mean monsoon season surface water availability were higher than that of mean annual ET during the post-1948 period (Fig. 10d). For instance, a significant decline $(\sim 10 \%)$ was noticed in Brahmani, Ganges, and Mahanadi basins while a significant increase was observed in the northeast coast and the Indus, Krishna, and Pennar basins (Fig. 10d, Table 1). The Ganges basin experienced a decline of $8 \%$ and the Indus basin witnessed an increase of $38 \%$ in mean monsoon season surface water availability during the post-1948 period (Table 1). We find that mean monsoon season changes in ET and surface water availability were strongly related to the changes in precipitation rather than air temperature (Fig. 10). For instance, mean monsoon season changes in air temperature did not show a strong association with the changes in evapotranspiration (Fig. 10) for most of the subcontinental river basins. However, a strong relationship between changes in precipitation and changes in ET was found in the subcontinental river basins (Fig. 10). These results highlight that the historic changes in ET and surface water availability were largely driven by the changes in precipitation rather than changes in air temperature (Fig. 10).

\section{f. Annual and monsoon season water budget in the subcontinental river basins}

Table 2 presents a water budget analysis during the monsoon season for the subcontinental river basins for the periods of 1901-47 and 1948-2012. Results showed that mean monsoon season precipitation in the Ganges, Brahmaputra, and Indus basins was 971, 1207, and $243 \mathrm{~mm}$, respectively, during the period of 1901-47. During the period of 1948-2012, mean monsoon season precipitation declined in the Ganges and Brahmaputra basins while it increased in the Indus basin. We find from the water budget analysis for the monsoon season that the subcontinental river basins that have relatively low precipitation (less than $500 \mathrm{~mm}$ ) showed higher atmospheric demands than total runoff [based on the ratios of evapotranspiration and precipitation $(\mathrm{ET} / P)$ and total runoff and precipitation $(\mathrm{TR} / P)]$. For instance, only eight basins showed runoff coefficient (TR/P) higher than ET/P ratio during the period of 1901-47 (Table 2). Our results show that partitioning of evapotranspiration (surface water availability) for the Brahmaputra, Ganges, Indus, Godavari, and Mahanadi basins was 34\%(45\%), $35 \%(46 \%), 59 \%(43 \%), 38 \%(37 \%)$, and $31 \%(47 \%)$ of mean monsoon precipitation during the period of 1948-2012. For the monsoon season, the analysis of the water budget components during the pre- and post-1948 periods revealed that the top four basins with the 

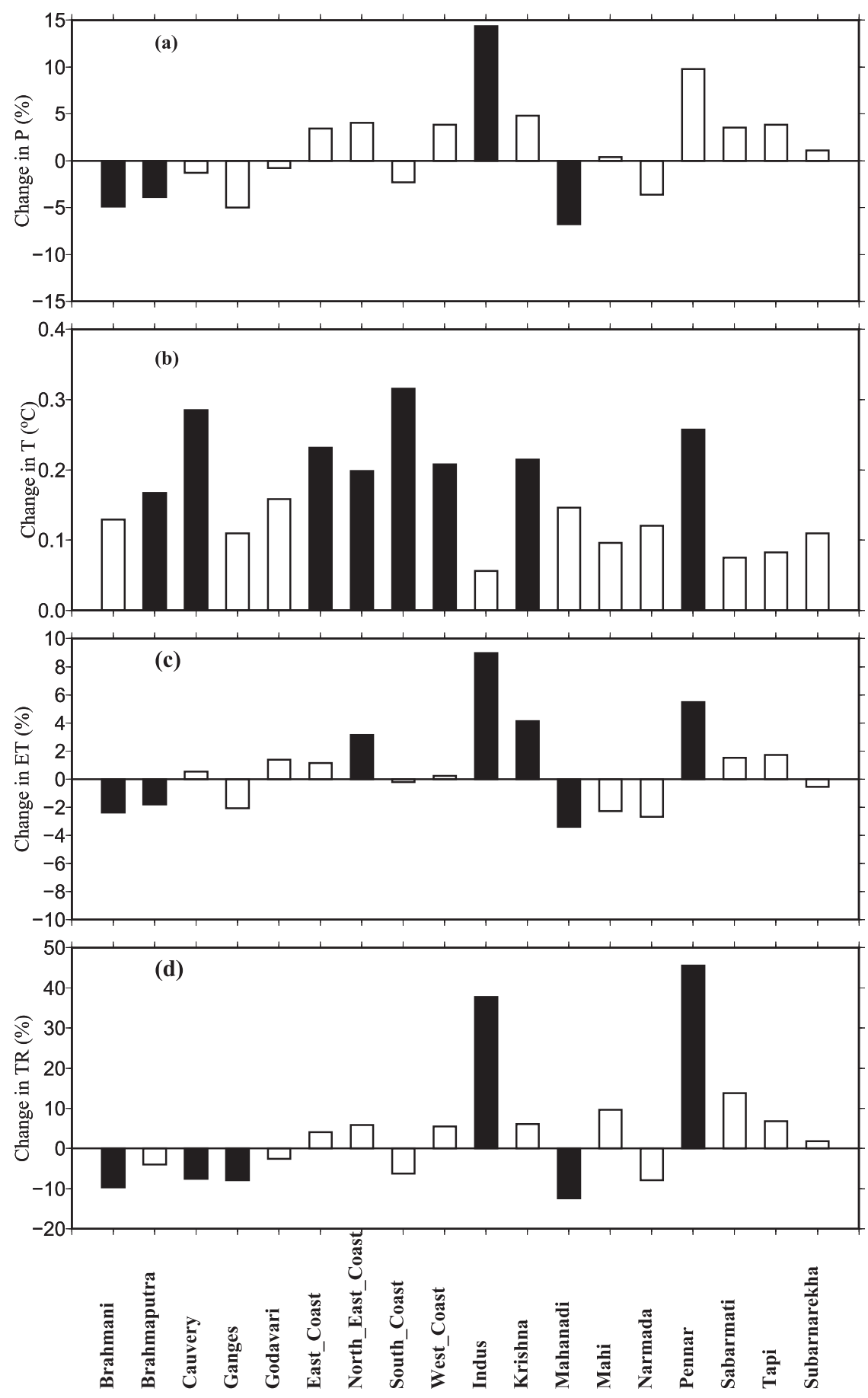

FIG. 10. Change in the monsoon season mean (a) $P$, (b) $T_{a}$, (c) ET, and (d) TR during the 1948-2012 period with respect to the 1901-47 period. Solid bars show significant changes in mean during the recent periods at $5 \%$ significance level estimated using the two-sided rank-sum test. Long-term mean values are presented in Table 2.

highest runoff ratio were Brahmaputra, west coast, Mahanadi, and Subarnarekha. The top four basins with the lowest runoff ratio were east coast, Mahi, Pennar, and Sabarmati (Table 2).
Annual water budget for the subcontinental river basins showed that only three basins (Brahmaputra, Subarnarekha, and west coast) are water surplus, with annual runoff more than $50 \%$ of mean annual precipitation 
TABLE 1. Changes in mean monsoon season water budget components during the 1948-2012 period with respect to the 190147 period.

\begin{tabular}{lrcrr}
\hline \multicolumn{1}{c}{ Basin } & $P(\%)$ & $T_{a}\left({ }^{\circ} \mathrm{C}\right)$ & ET $(\%)$ & TR $(\%)$ \\
\hline Brahmani & -4.9 & 0.1 & -2.4 & -9.7 \\
Brahmaputra & -3.9 & 0.2 & -1.8 & -3.9 \\
Cauvery & -1.3 & 0.3 & 0.5 & -7.5 \\
Ganges & -5.0 & 0.1 & -2.1 & -7.9 \\
Godavari & -0.8 & 0.2 & 1.4 & -2.6 \\
East coast & 3.5 & 0.2 & 1.2 & 4.1 \\
Northeast coast & 4.1 & 0.2 & 3.1 & 5.8 \\
South coast & -2.3 & 0.3 & -0.2 & -6.3 \\
West coast & 3.9 & 0.2 & 0.2 & 5.5 \\
Indus & 14.3 & 0.1 & 9.0 & 37.8 \\
Krishna & 4.8 & 0.2 & 4.1 & 6.1 \\
Mahanadi & -6.8 & 0.1 & -3.4 & -12.4 \\
Mahi & 0.4 & 0.1 & -2.3 & 9.6 \\
Narmada & -3.6 & 0.1 & -2.7 & -7.9 \\
Pennar & 9.8 & 0.3 & 5.5 & 45.6 \\
Sabarmati & 3.5 & 0.1 & 1.5 & 13.8 \\
Tapi & 3.8 & 0.1 & 1.7 & 6.8 \\
Subarnarekha & 1.1 & 0.1 & -0.5 & 1.8 \\
\hline
\end{tabular}

(Table 3). Therefore, a majority of the basins have evaporative demands more than $50 \%$ of total annual precipitation. There has been a large uncertainty in the estimations of mean annual ET in India and in the subcontinental river basins. For instance, the planning commission estimated ET as $40 \%$ of mean annual precipitation in India. Jain (2012) reported that evapotranspiration in India is $69.5 \%$ of the total annual precipitation. Based on our results for the entire domain of the subcontinental basins, annual ET and total runoff were $48 \%$ and $52 \%$, respectively. Jain (2012) reported that ET varied between $48.5 \%$ and $59.8 \%$ for the Narmada, Godavari, Cauvery, and Krishna basins. According to our results, annual ET in these basins ranged between $56.7 \%$ and $64.4 \%$. Differences in these estimates can be explained by the quality and source of the datasets. For instance, the estimates provided by Jain (2012) are based on the data from the planning commission, and our results are from the calibrated and evaluated hydrologic model at a much finer spatial resolution. The extent of the geographical domain in the two estimates is also different, as Jain (2012) did not consider the entire part of the Indus and Brahmaputra basins. Moreover, our results showed that mean annual ET was $51 \%$ and $56 \%$ of annual precipitation in the Ganges and Indus basins, respectively. However, significant differences in estimates from Jain (2012) were found for these two basins as they reported ET of $23 \%$ and $72 \%$ of annual precipitation, respectively.

\section{g. Role of large-scale climate variability on surface water availability}

To understand the role of large-scale climate variability on surface water availability in the subcontinental basins, we performed the SVD analysis on the SST departure field and total runoff anomalies for the monsoon season. Moreover, the SVD analysis was performed for the periods of 1901-47 and 1948-2012 to understand differences in coupled modes of variability in the SST departure field and surface water availability anomalies. First, two leading modes obtained from the SVD analysis were analyzed. Figure 11 shows the leading mode (mode 1) obtained using the SVD analysis of the SST departure field and

TABLE 2 . The monsoon season water budget components $(P, \mathrm{ET}$, and TR) and evaporative $(\mathrm{ET} / P)$ and runoff $(\mathrm{TR} / P)$ ratios for the periods of 1901-47 and 1948-2012.

\begin{tabular}{|c|c|c|c|c|c|c|c|c|c|c|}
\hline \multirow[b]{2}{*}{ Basin } & \multicolumn{5}{|c|}{$1901-47$} & \multicolumn{5}{|c|}{ 1948-2012 } \\
\hline & $P(\mathrm{~mm})$ & $\mathrm{ET}(\mathrm{mm})$ & $\mathrm{TR}(\mathrm{mm})$ & $\mathrm{ET} / P(\%)$ & $\mathrm{TR} / P(\%)$ & $P(\mathrm{~mm})$ & $\mathrm{ET}(\mathrm{mm})$ & $\mathrm{TR}(\mathrm{mm})$ & $\mathrm{ET} / P(\%)$ & $\mathrm{TR} / P(\%)$ \\
\hline Brahmani & 1199.7 & 395.3 & 567.5 & 33.0 & 47.3 & 1141.0 & 385.9 & 512.5 & 33.8 & 44.9 \\
\hline Brahmaputra & 1207.1 & 262.4 & 908.9 & 21.7 & 75.3 & 1160.3 & 257.6 & 873.0 & 22.2 & 75.2 \\
\hline Cauvery & 494.6 & 273.3 & 179.1 & 55.2 & 36.2 & 488.3 & 274.7 & 165.7 & 56.3 & 33.9 \\
\hline Ganges & 971.7 & 327.7 & 462.7 & 33.7 & 47.6 & 923.0 & 320.9 & 426.0 & 34.8 & 46.2 \\
\hline Godavari & 954.4 & 353.6 & 346.2 & 37.0 & 36.3 & 947.1 & 358.4 & 337.2 & 37.8 & 35.6 \\
\hline East coast & 383.7 & 301.6 & 75.7 & 78.6 & 19.7 & 396.9 & 305.1 & 78.8 & 76.9 & 19.8 \\
\hline Northeast coast & 815.5 & 314.7 & 293.8 & 38.6 & 36.0 & 848.7 & 324.5 & 311.0 & 38.2 & 36.6 \\
\hline South coast & 628.2 & 280.2 & 307.9 & 44.6 & 49.0 & 613.8 & 279.6 & 288.6 & 45.6 & 47.0 \\
\hline West coast & 1679.0 & 380.8 & 1145.7 & 22.7 & 68.2 & 1743.8 & 381.7 & 1209.1 & 21.9 & 69.3 \\
\hline Indus & 242.8 & 150.1 & 85.2 & 61.8 & 35.1 & 277.6 & 163.6 & 117.4 & 58.9 & 42.3 \\
\hline Krishna & 641.1 & 269.8 & 277.1 & 42.1 & 43.2 & 671.8 & 280.9 & 294.1 & 41.8 & 43.8 \\
\hline Mahanadi & 1225.7 & 370.5 & 621.0 & 30.2 & 50.7 & 1142.8 & 357.9 & 543.9 & 31.3 & 47.6 \\
\hline Mahi & 802.9 & 350.3 & 186.6 & 43.6 & 23.2 & 806.1 & 342.4 & 204.5 & 42.5 & 25.4 \\
\hline Narmada & 1047.8 & 365.5 & 445.1 & 34.9 & 42.5 & 1009.7 & 355.7 & 410.0 & 35.2 & 40.6 \\
\hline Pennar & 359.1 & 245.5 & 47.7 & 68.4 & 13.3 & 394.3 & 259.0 & 69.4 & 65.7 & 17.6 \\
\hline Sabarmati & 447.1 & 238.4 & 71.3 & 53.3 & 16.0 & 462.9 & 242.0 & 81.2 & 52.3 & 17.5 \\
\hline Tapi & 824.2 & 332.9 & 298.2 & 40.4 & 36.2 & 855.8 & 338.7 & 318.4 & 39.6 & 37.2 \\
\hline Subarnarekha & 1114.7 & 378.5 & 522.9 & 34.0 & 46.9 & 1126.8 & 376.5 & 532.3 & 33.4 & 47.2 \\
\hline
\end{tabular}


TABLE 3. Annual water budget components $(P$, ET, and TR) and evaporative $(\mathrm{ET} / P)$ and runoff $(\mathrm{TR} / P)$ ratios for the periods of $1901-47$ and 1948-2012.

\begin{tabular}{|c|c|c|c|c|c|c|c|c|c|c|}
\hline \multirow[b]{2}{*}{ Basin } & \multicolumn{5}{|c|}{$1901-47$} & \multicolumn{5}{|c|}{ 1948-2012 } \\
\hline & $P(\mathrm{~mm})$ & $\mathrm{ET}(\mathrm{mm})$ & $\mathrm{TR}(\mathrm{mm})$ & $\mathrm{ET} / P(\%)$ & $\mathrm{TR} / P(\%)$ & $P(\mathrm{~mm})$ & $\mathrm{ET}(\mathrm{mm})$ & $\mathrm{TR}(\mathrm{mm})$ & $\mathrm{ET} / P(\%)$ & $\mathrm{TR} / P(\%)$ \\
\hline Brahmani & 1529.4 & 765.6 & 755.5 & 50.1 & 49.4 & 1435.0 & 746.7 & 688.5 & 52.0 & 48.0 \\
\hline Brahmaputra & 1697.5 & 431.6 & 1230.5 & 25.4 & 72.5 & 1650.7 & 422.4 & 1195.1 & 25.6 & 72.4 \\
\hline Cauvery & 1057.3 & 681.4 & 370.8 & 64.4 & 35.1 & 1007.1 & 670.2 & 336.8 & 66.5 & 33.4 \\
\hline Ganges & 1166.4 & 578.7 & 571.4 & 49.6 & 49.0 & 1112.9 & 569.2 & 532.7 & 51.1 & 47.9 \\
\hline Godavari & 1150.9 & 695.3 & 446.2 & 60.4 & 38.8 & 1125.6 & 695.8 & 430.5 & 61.8 & 38.2 \\
\hline East coast & 1004.9 & 686.0 & 295.1 & 68.3 & 29.4 & 969.4 & 681.9 & 285.7 & 70.3 & 29.5 \\
\hline Northeast coast & 1213.4 & 690.2 & 510.7 & 56.9 & 42.1 & 1238.0 & 706.6 & 531.7 & 57.1 & 43.0 \\
\hline South coast & 1425.9 & 775.8 & 633.0 & 54.4 & 44.4 & 1347.4 & 757.0 & 587.4 & 56.2 & 43.6 \\
\hline West coast & 2026.7 & 706.2 & 1318.6 & 34.8 & 65.1 & 2078.7 & 703.3 & 1375.5 & 33.8 & 66.2 \\
\hline Indus & 436.1 & 267.1 & 157.5 & 61.2 & 36.1 & 513.6 & 289.8 & 211.8 & 56.4 & 41.2 \\
\hline Krishna & 873.2 & 511.6 & 361.5 & 58.6 & 41.4 & 904.3 & 526.8 & 377.8 & 58.3 & 41.8 \\
\hline Mahanadi & 1459.6 & 705.9 & 749.4 & 48.4 & 51.3 & 1334.6 & 680.2 & 654.8 & 51.0 & 49.1 \\
\hline Mahi & 857.4 & 607.2 & 236.4 & 70.8 & 27.6 & 855.4 & 600.5 & 254.9 & 70.2 & 29.8 \\
\hline Narmada & 1172.8 & 664.5 & 500.6 & 56.7 & 42.7 & 1102.0 & 647.8 & 454.7 & 58.8 & 41.3 \\
\hline Pennar & 720.2 & 513.6 & 206.6 & 71.3 & 28.7 & 756.9 & 528.9 & 227.9 & 69.9 & 30.1 \\
\hline Sabarmati & 479.4 & 380.5 & 90.7 & 79.4 & 18.9 & 495.6 & 391.6 & 103.1 & 79.0 & 20.8 \\
\hline Tapi & 936.6 & 592.2 & 342.0 & 63.2 & 36.5 & 948.1 & 595.7 & 353.4 & 62.8 & 37.3 \\
\hline Subarnarekha & 1447.5 & 694.9 & 740.7 & 48.0 & 51.2 & 1444.3 & 687.9 & 756.6 & 47.6 & 52.4 \\
\hline
\end{tabular}

surface water availability anomalies during the periods of 1901-47 and 1948-2012. For the 1901-47 period, strong correlation patterns between SST departure field and surface water availability for the monsoon season were revealed in the central Pacific Ocean and in the Atlantic Ocean (Figs. 11a,b). This mode resembles a typical El Niño-Southern Oscillation (ENSO), highlighting that warmer SST anomalies in the central Pacific Ocean result in weaker surface water availability over the Indian landmass (Mishra et al. 2012). We obtained ENSO as a leading mode of coupled variability between SST and surface water availability for the period of 1948-2012 (Figs. 11c,d). However, it was found that the influence of ENSO on surface water availability anomalies weakened during the post-1948 period (Figs. 11e,f).

Substantial differences in the first mode obtained for the two periods (e.g., 1901-47 and 1948-2012) in the heterogeneous correlation patterns were exhibited in the Indian and Atlantic Oceans. Moreover, SCF was reduced from $77.6 \%$ to $66 \%$ for the pre- and post- 1948 periods, respectively. These results highlight the weakening of the ENSO and total runoff relationship (Table S6 in the supplemental material) during the period of 1901-2012, which is consistent with the previous studies (Kumar et al. 1999). Kumar et al. (1999) reported that the weakening of the ENSO and Indian monsoon relationship may be due to a southward shift in the Walker circulation anomalies and an increased surface temperature over Eurasia during winter and spring seasons. The correlation coefficient between the first principal component (PC1) of SST departure fields obtained from the SVD analysis and surface water availability anomalies during the monsoon season declined during 19482012 in the many subcontinental river basins (Table S7 in the supplemental material). For instance, out of 18 basins, 11 showed a decline in the correlation coefficient during the period of 1948-2012. Basins in which the ENSO and total runoff relationship was found to be strengthened during the period of 1948-2012 were Brahmaputra, Ganges, northeast coast, south coast, Mahanadi, and Subarnarekha.

The second mode resembles the trend patterns obtained for surface water availability during the monsoon season for the periods of 1901-47 (Figs. 12a,b) and 19482012 (Figs. 12c,d). The second mode for the period of 1901-47 explained $11.7 \%$ of the total squared covariance while the correlation coefficient between principal components of SST departure field and total runoff anomalies was 0.81 . We find that positive SST anomalies in the Atlantic Ocean resulted in increased surface water availability in the subcontinental basins located in central India (i.e., Narmada, Mahanadi, and Tapi). Therefore, increasing trends in surface water availability in these basins may be partially associated with SST anomalies in the Atlantic Ocean and South China Sea (Figs. 12a,b). During the period of 1948-2012, positive SST anomalies in the Indian Ocean and southern Atlantic Ocean resulted in the decreasing trend in surface water availability during the monsoon season in the Gangetic Plain region (Figs. 12c,d). The difference in heterogeneous correlation patterns indicated that warming in the southwestern Indian Ocean and southern 
(a) First Mode (1901-1947) [ SCF $=77.6 \%, r=0.77]$

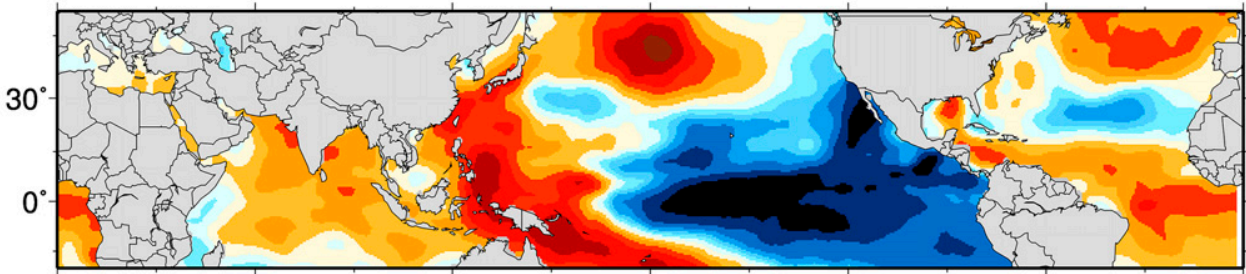

(c) First Mode (1948-2012) [ SCF $=66 \%, r=0.76]$

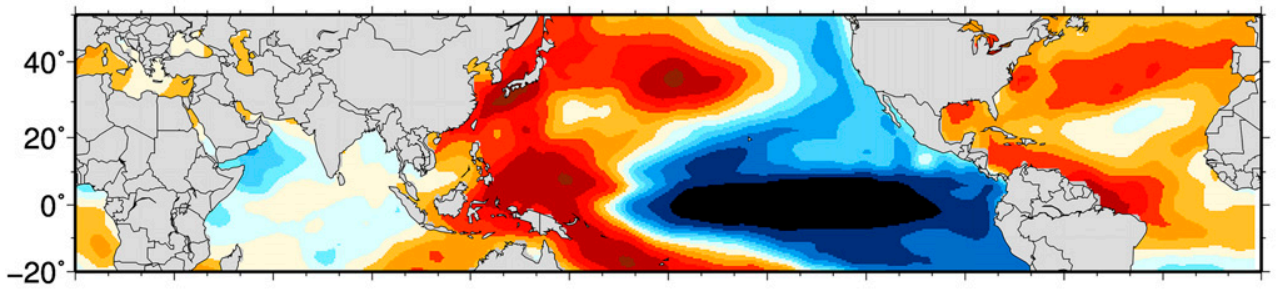

(e) Difference

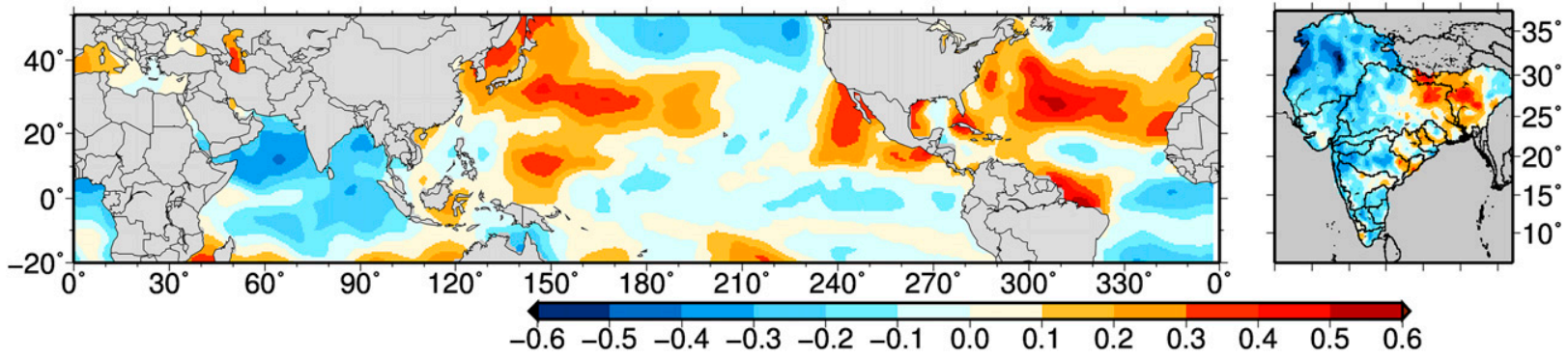

FIG. 11. The first mode of coupled patterns of SST and TR variability for the monsoon (JJAS) season estimated using the SVD analysis for the periods of (a),(b) 1901-47 and (c),(d) 1948-2012. (e),(f) Difference (1948-2012 minus 1901-47) of heterogeneous correlation pattern of the first modes obtained for the 1901-47 and 1948-2012 periods. The analysis was performed using the SST departure field and standardized anomalies of surface water availability. Shaded patterns show heterogeneous correlation between (a), (c) SST departure field and (b),(d) TR for the monsoon season. Numbers in brackets show SCF and $r$ between principal components of SST and TR.

Atlantic Ocean may be associated with the decline in the monsoon season water availability in the Gangetic Plain region. These results are consistent with the findings of Mishra et al. (2012) and Koll et al. (2015). However, Bollasina et al. (2011) reported that the decline in the monsoon season precipitation over the Gangetic Plain is related to human-induced aerosol emissions. We also noticed that the squared covariance between SST departure field and surface water availability anomalies increased during the recent period, which highlights the dominating role of the Indian and Atlantic Oceans on the surface water availability in the Gangetic Plain region (Figs. 12c-f).

To further understand the role of Indian Ocean SSTs on water availability in the subcontinental basins, we estimated changes in SST during the period of 1948-2012 (Fig. 13a). Our results show that parts of the Indian Ocean experienced more than $1^{\circ} \mathrm{C}$ warming during the period of 1948-2012 (Fig. 13a); however, an increasing trend in SST can be noticed in the Indian Ocean from 1901 onward. Despite the increasing trends in the Indian Ocean SST during the period of 1901-47, total runoff during the monsoon season increased. Persistent warming in the Indian Ocean may lead to serious implications on surface water availability in the subcontinental basins as reflected by the correlation patterns between the domain-averaged SST anomaly and total runoff in the monsoon season (Figs. 13c,d). For both periods, correlation patterns resemble the trend in surface water availability during the monsoon season (Figs. 13c,d). Moreover, correlations between the Indian Ocean SST and surface water availability exhibit the role of Indian Ocean SST in surface water availability during the preand post-1948 periods.

\section{Conclusions}

We analyzed hydrologic changes and water budget in the Indian subcontinental river basins during the period of 1901-2012. The sequential Mann-Kendall test on the domain-averaged monsoon season precipitation showed the changepoint in 1947. Here it would be important to note that individual basins may have different changepoints 
(a) Second Mode (1901-1947) [ SCF $=11.7 \%, r=0.81]$

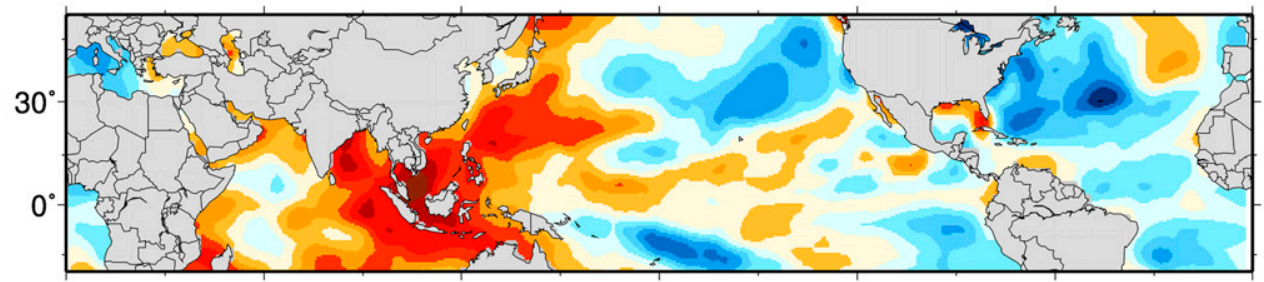

(c) Second Mode (1948-2012) [ SCF $=23 \%, r=0.85$ ]

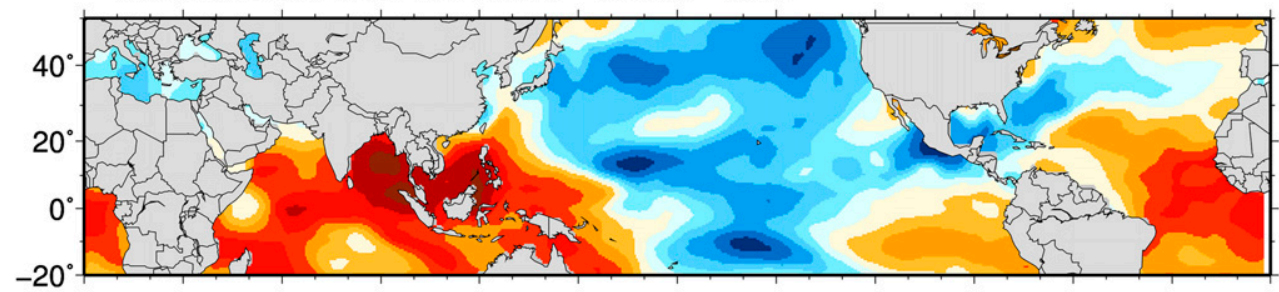

(e) Difference

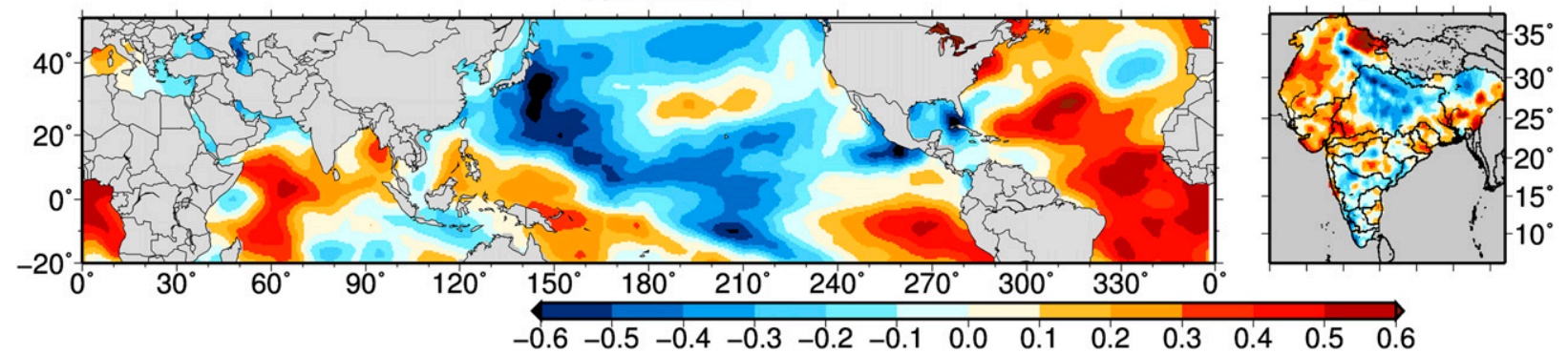

FIG. 12. As in Fig. 11, but for the second mode. Numbers in brackets show SCF and $r$ between principal components of SST and surface water availability.

for the hydroclimatic variables, which may be considered in the basin-specific analysis in future. Based on the changepoint for the subcontinent domain, trends and changes in water budget were analyzed for the pre- and post1948 periods. Our results showed that the monsoon season precipitation increased significantly during the period of 1901-47 in seven subcontinental river basins. In the pre-1948 period, out of 18 river basins, 15 basins showed increasing trends in the monsoon season precipitation. The majority of the subcontinental basins experienced declining trends; however, only the Ganges basin showed significantly declining trends in the monsoon season precipitation during the period of 1948-2012. During the post-1948 period, 15 out of the total 18 river basins experienced significant warming during the monsoon season, which largely occurred during the period of 1975-2012. Analysis of VIC-simulated ET and surface water availability for the two periods revealed major changes in the subcontinental river basins. While the majority of the subcontinental basins experienced increases in the monsoon season ET in the pre-1948 period, significant declines in ET were found in the Ganges, Mahanadi, Mahi, Narmada, and Tapi basins.

(b)

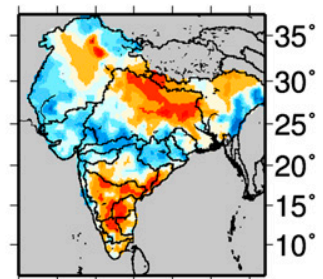

(d)

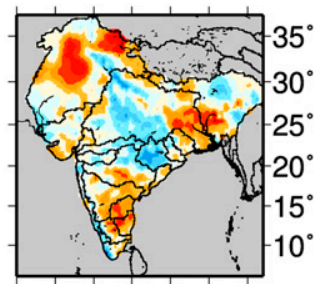

(f) . . 
(a) Change in SST 1948-2012

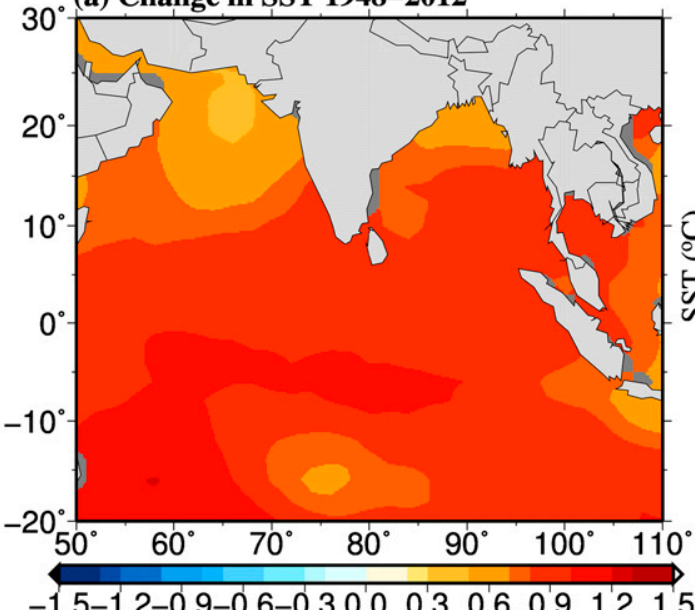

(c) Correlation (1901-1947)

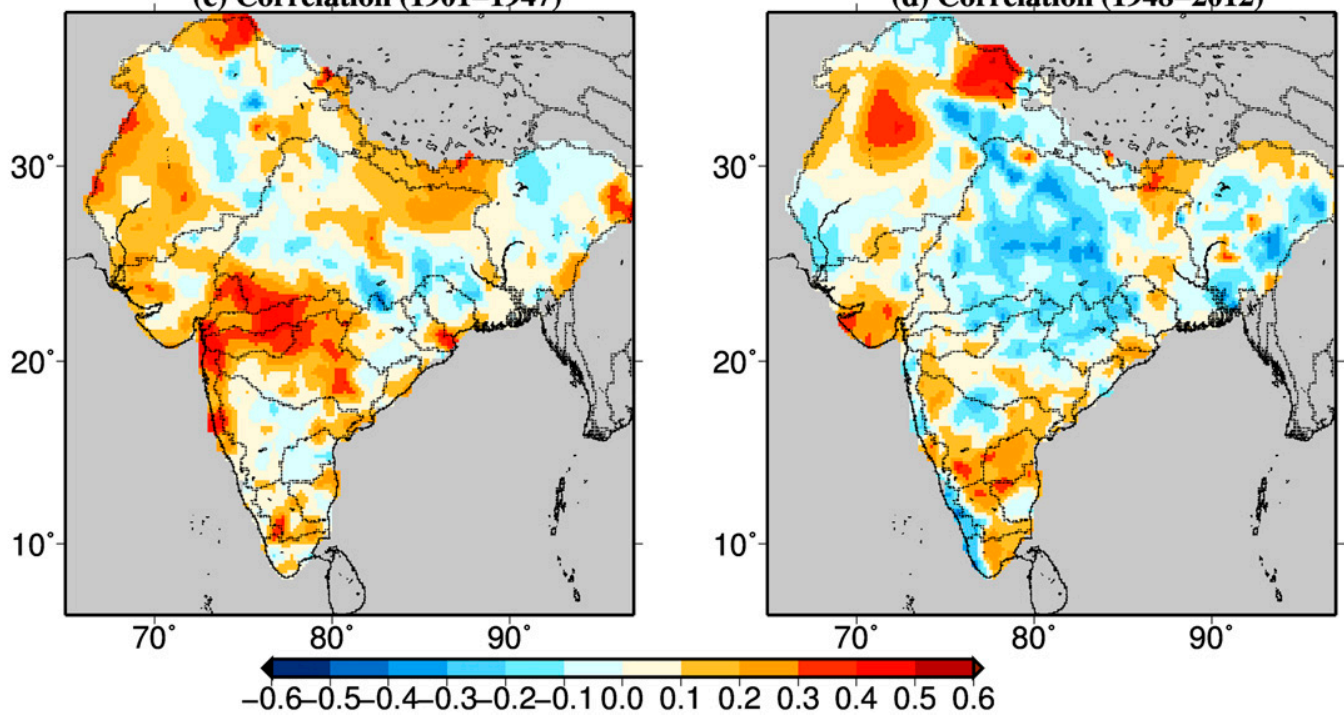

(b) Indian Ocean SST

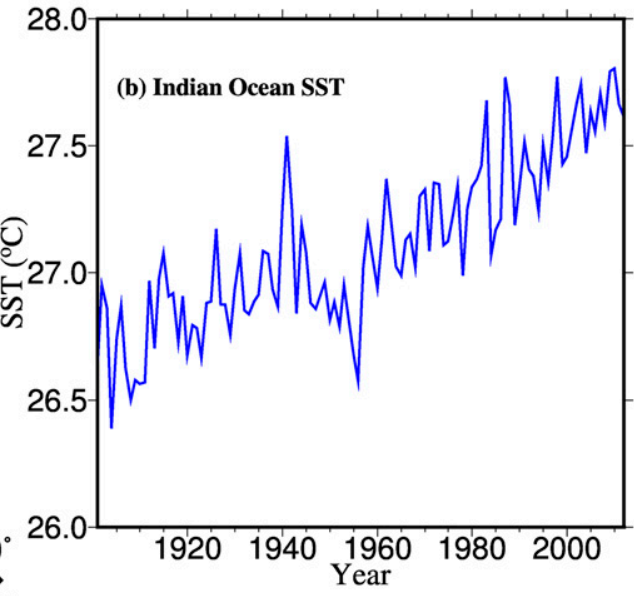

(d) Correlation (1948-2012)

FIG. 13. (a) Change in SST in the Indian Ocean during the period of 1948-2012; (b) domain-averaged time series of the Indian Ocean SST during the period of 1901-2012; (c) correlation between domain-averaged Indian Ocean SST and TR for the monsoon season during the period of 1901-47; and (d) as in (c), but for the period of 1948-2012. air temperature that influence the water budget in coming decades. Our results highlight the need for understanding the role of natural climate variability, anthropogenic climate change, and land-use/land-cover changes on surface water availability in the subcontinental basins before planning for interbasin water transfer through river linking.

a. How has surface water availability, as measured by total runoff, changed across India's subcontinental river basins?

The Indian subcontinental basins experienced substantial changes in surface water availability in the preand post-1948 periods. For instance, out of 18, 10 river basins experienced significant increases in the monsoon season total runoff during the period of 1901-47, while eight basins experienced declines in total runoff in the post-1948 period. However, a significant decline was not observed in any of the subcontinental basins during the post-1948 period. The major river basins that experienced declines in mean monsoon season surface water availability in the post-1948 period were the Brahmaputra (4\%), Ganges (8\%), Mahanadi (12\%), Cauvery $(7.5 \%)$, and Narmada ( $8 \%$ ) basins. Our results showed that surface water availability during the pre1948 period was higher in most of the river basins than the post-1948 period. 
b. What are the key drivers of those changes (e.g., precipitation, ET, and air temperature) during the monsoon season?

Since majority of the subcontinental river basins fall in the tropical and subtropical climate regime, monsoon season precipitation is a major driver of ET and surface water availability. For instance, mean changes in ET and surface water availability are strongly related with the changes in precipitation. Surface water availability in most of the river basins is more sensitive to changes in precipitation than that of air temperature. For instance, decline in mean monsoon season precipitation of $5 \%$ in the Ganges River basin translated into a decline of $8 \%$ and $2 \%$ in total runoff and ET, respectively, in the post1948 period. Moreover, $14 \%$ and $10 \%$ increases in the monsoon season precipitation resulted in increases of $38 \%$ and $47 \%$ in mean monsoon season surface water availability in the Indus and Pennar basins. Overall, the monsoon season precipitation derives the surface water availability in the Indian subcontinent, and impact of observed warming on surface water availability was found to be lower. However, if a prominent warming (e.g., post1975 period) continues in the future, substantial changes in the partitioning of water budget components may occur in the subcontinental river basins, as most of them are water limited with lower runoff ratios.

c. How are these trends related to large-scale climate patterns, as measured by SSTs, and what does this mean for future surface water availability?

We found that in the most of the subcontinental river basins ENSO and Indian Ocean SST (leadings modes obtained from the SVD analysis) affected surface water availability during the pre- and post-1948 periods. Consistent with previous studies (Mishra et al. 2012; Koll et al. 2015), a positive SST anomaly in the Pacific and Indian Oceans results in a precipitation deficit in the majority of the subcontinent and in the Indo-Gangetic Plain, respectively. Under a warming climate, the dominant modes of variability in the monsoon season precipitation may change, which will affect surface water availability in the subcontinental river basins. Moreover, the prominent modes of variability estimated for individual basins may be different than that of obtained for the entire domain, which can be analyzed in the basin-specific studies.

Acknowledgments. The datasets used in this study are available through India Meteorological Department (IMD, http://www.imdaws.com/viewawsdata.aspx), Princeton University (http://hydrology.princeton.edu/data. php), and NOAA (http://www.esrl.noaa.gov/psd/data/ gridded/data.noaa.ersst.html). The authors acknowledge funding from MHRD, ITRA-Water, National Environmental Science Fellowship (Ministry of Environment and Forest), and Varahamihira Research Fellowship (Ministry of Earth Sciences). The authors appreciate constructive comments from three anonymous reviewers. This work is part of the ITRA project: Measurement to Management (M2M): Improved Water Use Efficiency and Agricultural Productivity through Experimental Sensor Network.

\section{REFERENCES}

Asharaf, S., and B. Ahrens, 2015: Indian summer monsoon rainfall processes in climate change scenarios. J. Climate, 28, 5414-5429, doi:10.1175/JCLI-D-14-00233.1.

Ashfaq, M., Y. Shi, W. Tung, R. J. Trapp, X. Gao, J. S. Pal, and N. S. Diffenbaugh, 2009: Suppression of south Asian summer monsoon precipitation in the 21st century. Geophys. Res. Lett., $\mathbf{3 6}$ L01704, doi:10.1029/2008GL036500.

Bollasina, M. A., Y. Ming, and V. Ramaswamy, 2011: Anthropogenic aerosols and the weakening of the South Asian summer monsoon. Science, 334, 502-505, doi:10.1126/science.1204994.

Bretherton, C. S., C. Smith, and J. M. Wallace, 1992: An intercomparison of methods for finding coupled patterns in climate data. J. Climate, 5, 541-560, doi:10.1175/1520-0442(1992)005<0541: $\mathrm{AIOMFF}>2.0 . \mathrm{CO} ; 2$.

Cook, E. R., P. J. Krusic, and P. D. Jones, 2003: Dendroclimatic signals in long tree-ring chronologies from the Himalayas of Nepal. Int. J. Climatol., 23, 707-732, doi:10.1002/joc.911.

Fowler, H. J., and D. R. Archer, 2006: Conflicting signals of climatic change in the upper Indus basin. J. Climate, 19, 4276-4293, doi:10.1175/JCLI3860.1.

Gao, H., and Coauthors, 2010: Water budget record from Variable Infiltration Capacity (VIC) model. Algorithm Theoretical Basis Doc., 56 pp. [Available online at http://www.hydro.washington. edu/SurfaceWaterGroup/Publications/Water_Cycle_MEaSUREs_ ATBD_VICmodel_submit.doc.]

Goswami, B. N., M. S. Madhusoodanan, C. P. Neema, and D. Sengupta, 2006: A physical mechanism for North Atlantic SST influence on the Indian summer monsoon. Geophys. Res. Lett., 33, L02706, doi:10.1029/2005GL024803.

Hansen, J., M. Sato, R. Ruedy, K. Lo, D. W. Lea, and M. MedinaElizade, 2006: Global temperature change. Proc. Natl. Acad. Sci. USA, 103, 14 288-14 293, doi:10.1073/pnas.0606291103.

Hansen, M. C., R. S. DeFries, J. R. Townshend, and R. Sohlberg, 2000: Global land cover classification at $1 \mathrm{~km}$ spatial resolution using a classification tree approach. Int. J. Remote Sens., 21, 1331-1364, doi:10.1080/014311600210209.

Hollmann, R., and Coauthors, 2013: The ESA climate change initiative: Satellite data records for essential climate variables. Bull. Amer. Meteor. Soc., 94, 1541-1552, doi:10.1175/ BAMS-D-11-00254.1.

Immerzeel, W. W., L. P. H. van Beek, and M. F. P. Bierkens, 2010: Climate change will affect the Asian water towers. Science, 328, 1382-1385, doi:10.1126/science.1183188.

Jain, S. K., 2012: India's water balance and evapotranspiration. Curr. Sci., 102, 964-967.

Jung, M., and Coauthors, 2010: Recent decline in the global land evapotranspiration trend due to limited moisture supply. Nature, 467, 951-954, doi:10.1038/nature09396.

Koll, M., K. Ritika, P. Terray, R. Murtugudde, K. Ashok, and B. N. Goswami, 2015: Drying of Indian subcontinent by rapid Indian 
Ocean warming and a weakening land-sea thermal gradient. Nat. Commun., 6, 7423, doi:10.1038/ncomms 8423 .

Krishnan, R., and M. Sugi, 2003: Pacific decadal oscillation and variability of the Indian summer monsoon rainfall. Climate Dyn., 21, 233-242, doi:10.1007/s00382-003-0330-8.

Kumar, K. K., B. Rajagopalan, and M. A. Cane, 1999: On the weakening relationship between the Indian monsoon and ENSO. Science, 284, 2156-2159, doi:10.1126/science.284.5423.2156.

_ - and Coauthors, 2011: The once and future pulse of Indian monsoonal climate. Climate Dyn., 36, 2159-2170, doi:10.1007/ s00382-010-0974-0.

Liang, X., D. P. Lettenmaier, and E. F. Wood, 1996: One-dimensional statistical dynamic representation of subgrid spatial variability of precipitation in the two-layer Variable Infiltration Capacity model. J. Geophys. Res., 101, 21 403-21 422, doi:10.1029/96JD01448.

Mann, H. B., 1945: Nonparametric tests against trend. Econometrica, 13, 245-259, doi: $10.2307 / 1907187$.

McVicar, T. R., and Coauthors, 2012: Global review and synthesis of trends in observed terrestrial near-surface wind speeds: Implications for evaporation. J. Hydrol., 416-417, 182-205, doi:10.1016/j.jhydrol.2011.10.024.

Menon, A., A. Levermann, J. Schewe, J. Lehmann, and K. Frieler, 2013: Consistent increase in Indian monsoon rainfall and its variability across CMIP-5 models. Earth Syst. Dyn., 4, 287-300, doi:10.5194/esd-4-287-2013.

Mishra, V., 2015: Climatic uncertainty in Himalayan water towers. $J$. Geophys. Res. Atmos., 120, 2689-2705, doi:10.1002/2014JD022650.

—, and D. P. Lettenmaier, 2011: Climatic trends in major US urban areas, 1950-2009. Geophys. Res. Lett., 38, L16401, doi:10.1029/2011GL048255.

__ , and R. Lilhare, 2016: Hydrologic sensitivity of Indian subcontinental river basins to climate change. Global Planet. Change, 139, 78-96, doi:10.1016/j.gloplacha.2016.01.003.

— K. K. Cherkauer, and L. C. Bowling, 2010: Parameterization of lakes and wetlands for energy and water balance studies in the Great Lakes region. J. Hydrometeor., 11, 1057-1082, doi:10.1175/2010JHM1207.1.

_ _ _ _ _ _ and M. Huber, 2011: Lake ice phenology of small lakes: Impacts of climate variability in the Great Lakes region. Global Planet. Change, 76, 166-185, doi:10.1016/ j.gloplacha.2011.01.004.

— B. B. Smoliak, D. P. Lettenmaier, and J. M. Wallace, 2012: A prominent pattern of year-to-year variability in Indian summer monsoon rainfall. Proc. Natl. Acad. Sci. USA, 109, 7213-7217, doi:10.1073/pnas.1119150109.

_, R. Shah, and B. Thrasher, 2014: Soil moisture droughts under the retrospective and projected climate in India. J. Hydrometeor., 15, 2267-2292, doi:10.1175/JHM-D-13-0177.1.

_ A. R. Ganguly, B. Nijssen, and D. P. Lettenmaier, 2015: Changes in observed climate extremes in global urban areas. Environ. Res. Lett., 10, 024005, doi:10.1088/1748-9326/10/2/024005.

Mu, Q., M. Zhao, and S. W. Running, 2011: Improvements to a MODIS global terrestrial evapotranspiration algorithm. Remote Sens. Environ., 115, 1781-1800, doi:10.1016/j.rse.2011.02.019.
Nash, J. E., and J. V. Sutcliffe, 1970: River flow forecasting through conceptual models part I-A discussion of principles. J. Hydrol., 10, 282-290, doi:10.1016/0022-1694(70)90255-6.

Olmo, F. J., and L. Alados-Arboledas, 1995: Pinatubo eruption effects on solar radiation at Almeria $\left(36.83^{\circ} \mathrm{N}, 2.41^{\circ} \mathrm{W}\right)$. Tellus, 47B, 602-606, doi:10.1034/j.1600-0889.47.issue5.7.x.

Pai, D. S., L. Sridhar, M. R. Badwaik, and M. Rajeevan, 2014a: Analysis of the daily rainfall events over India using a new long period (1901-2010) high resolution $\left(0.25^{\circ} \times 0.25^{\circ}\right)$ gridded rainfall data set. Climate Dyn., 45, 755-776, doi:10.1007/ s00382-014-2307-1.

$\longrightarrow$ - M. Rajeevan, O. P. Sreejith, N. S. Satbhai, and B. Mukhopadhyay, 2014b: Development of a new high spatial resolution $\left(0.25^{\circ} \times 0.25^{\circ}\right)$ long period $(1901-2010)$ daily gridded rainfall data set over India and its comparison with existing data sets over the region. Mausam, 65, 1-18.

Rajeevan, M., J. Bhate, and A. K. Jaswal, 2008: Analysis of variability and trends of extreme rainfall events over India using 104 years of gridded daily rainfall data. Geophys. Res. Lett., 35, L18707, doi:10.1029/2008GL035143; Corrigendum, 35, L23701, doi:10.1029/2008GL036105.

Ramanathan, V., and M. V. Ramana, 2005: Persistent, widespread, and strongly absorbing haze over the Himalayan foothills and the Indo-Gangetic Plains. Pure Appl. Geophys. 162, 1609-1626, doi:10.1007/s00024-005-2685-8.

Sen, P. K., 1968: Estimates of the regression coefficient based on Kendall's tau. J. Amer. Stat. Assoc., 63, 1379-1389, doi:10.1080/ 01621459.1968 .10480934$.

Shah, R. D., and V. Mishra, 2015: Development of an experimental near-real-time drought monitor for India. J. Hydrometeor., 16, 327-345, doi:10.1175/JHM-D-14-0041.1.

Sheffield, J., and E. F. Wood, 2007: Characteristics of global and regional drought, 1950-2000: Analysis of soil moisture data from off-line simulation of the terrestrial hydrologic cycle. J. Geophys. Res., 112, D17115, doi:10.1029/2006JD008288.

_, G. Goteti, and E. F. Wood, 2006: Development of a 50-year highresolution global dataset of meteorological forcings for land surface modeling. J. Climate, 19, 3088-3111, doi:10.1175/JCLI3790.1.

Smith, T. M., R. W. Reynolds, T. C. Peterson, and J. Lawrimore, 2008: Improvements to NOAA's historical merged land-ocean surface temperature analysis (1880-2006). J. Climate, 21, 2283-2296, doi:10.1175/2007JCLI2100.1.

Sneyers, R., 1990: On statistical analysis of series of observations. WMO Tech. Note 143, $192 \mathrm{pp}$.

Turner, A. G., and H. Annamalai, 2012: Climate change and the South Asian summer monsoon. Nat. Climate Change, 2, 587-595, doi:10.1038/nclimate1495.

Vörösmarty, C. J., P. Green, J. Salisbury, and R. B. Lammers, 2000: Global water resources: Vulnerability from climate change and population growth. Science, 289, 284-288, doi:10.1126/ science.289.5477.284.

Yue, S., and C. Y. Wang, 2002: Applicability of prewhitening to eliminate the influence of serial correlation on the Mann-Kendall test. Water Resour. Res., 38, 1068, doi:10.1029/2001WR000861. 